Discussion Paper 79

Institute for Empirical Macroeconomics

Federal Reserve Bank of Minneapolis

Research Department

250 Marquette Avenue

Minneapolis, Minnesota 55480-0291

February 1993

\title{
Cyclical Factor Utilization
}

\author{
Mark Bils* \\ University of Rochester \\ Jang-Ok Cho* \\ Queen's University
}

\begin{abstract}
We introduce procyclical labor and capital utilization, as well as costs of rapidly increasing employment, into a business-cycle model. Plausible variations in factor utilization enable us to explain observed variability of real GNP with considerably smaller economy-wide disturbances. The costs of adjustment create very interesting and realistic lead and lag relationships: Employment does not peak until a full quarter after output; workweeks, effort, capital utilization, and productivity all sharply lead the business cycle.
\end{abstract}

*Bils acknowledges financial support from the National Science Foundation and from the James S. Kemper Foundation. We have benefited from helpful comments from a referee as well as participants at several seminars.

Any opinions, findings, conclusions, or recommendations expressed herein are those of the authors and not necessarily those of the National Science Foundation, the University of Minnesota, the Federal Reserve Bank of Minneapolis, or the Federal Reserve System. 


\section{Introduction}

Total factor productity (though not labor productivity) is quite procyclical. The traditional explanation for this finding is that hired inputs, both labor and capital, are used more intensively in booms than in contractions (e.g., Jorgenson and Griliches, 1967). We examine cyclical factor utilization within a real-business-cycle model. We find this a useful combination. We can judge the importance of plausible movements in capital and labor utilization in the broader picture of cyclical movements in inputs and cyclical movements in productivity. We can also examine to what extent cyclical utilization helps our realbusiness-cycle model in matching the character of actual business cycles in the United States.

We require that our model economy be capable of displaying the following businesscycle features: Important fluctuations occur both in employment and in weekly hours per worker; movements in hours per week lead movements in employment over the cycle; productivity movements (measured by total factor productivity or labor productivity) lead the cycle, and particularly lead employment. (These regularities are documented, among other places, in Kydland and Prescott, 1990.)

Several earlier papers have captured movements in both employment and hours (e.g.,

Cho and Rogerson, 1987, and Cho and Cooley, 1988) We do so by realisticly making hours per week and weeks per year of leisure imperfect substitutes. We calibrate these relative movements by examining micro data on how workers vary hours and weeks of work. We introduce costs of adjusting the capital matched to each worker in order to make employment lag behind output and behind hours per week over the cycle. Employment adjusts slowly in order to give the capital stock opportunity to keep pace. Hansen and 
Sargent (1988) have previously introduced costs of adjusting employment in a real-businesscycle model. We pick the size of adjustment costs to match cyclical movements in labor's share in output.

We introduce procyclical utilization for both labor and capital. We consider workers with preferences over weeks of work, hours per week of work, and effort per hour at work. A disturbance that causes workers to take less leisure at home should potentially cause them to take less leisure at work. This implies a close relationship between potential movements in effort and observed movements in the workweek. We choose preferences so that the relative movements in hours per week and effort match time-motion studies reported in Schor (1987). We assume that the utilization rate of capital increases when workers work longer workweeks or work at a higher level of effort. We provide some evidence that capital utilization does respond significantly to movements in weekly hours of work. The close relationship we model between hours per worker and utilization of capital and effort implies that productivity is much more positively correlated with movements in hours per worker than with employment. Because hours per worker leads the cycle, productivity strongly leads the cycle for our model economy. Burnside, Eichenbaum, and Rebello (1990) achieve a similar result in a model where all labor adjustments in the initial period after a disturbance must take the form of changes in effort.

Our model performs better than prior real-business-cycle models in that, consistent with actual cycles, employment lags the business cycle and productivity leads the cycle. Nevertheless, the model falls very far short of generating fluctuations that look like observed business cycles. In particular, total labor hours are much less variable for the model than in the data; productivity is much more procyclical for the model than in the data. In the concluding section we discuss introducing further disturbances, disturbances 
other than productivity shocks, to explain this large discrepancy. In particular, we examine how utilization and productivity respond to a shift in preferences that generates a boom through increased demand for consumption.

\section{Utilization in a Model Economy}

We relax three assumptions that are typically made in modelling aggregate production. We relax the assumption that workers' effort while at work does not fluctuate. Effective hours of labor can be varied by increasing the intensity of effort at work, as well as by varying the number of workers and the number of hours at work per worker. We relax the assumption of a given short-run quantity of capital. We assume instead that a given stock of capital is utilized more intensively when workers are working longer hours or working at a more rapid pace. Thirdly, we relax the assumption that the capital-labor ratio can be costlessly changed in the short run. We allow for costs of changing the amount of capital matched with each worker. Each of these three features of our model is discussed and defended empirically.

\section{Production}

We follow Kydland and Prescott (1982) by assuming a constant-returns-to-scale CobbDouglas aggregate production function, subject to multiplicative technology disturbances. Output is produced from effective units of labor, $L$, and effective units of capital, $K$ ': 


$$
Y_{t}=Z_{t}\left(L_{t}\right)^{\alpha}\left(K_{t}^{\prime}\right)^{1-\alpha}
$$

We also follow calculations of labor's share in Kydland and Prescott, and choose a value for $\alpha$ of 0.64 .

We allow three dimensions to effective labor units: employment, N, hours per worker, $\mathrm{H}$, and effort per hour at work, $\phi . \mathrm{L}$ is therefore given by:

$$
\mathrm{L}_{\mathrm{t}}=\phi_{\mathrm{t}} \mathrm{H}_{\mathrm{t}} \mathrm{N}_{\mathrm{t}}
$$

There are potentially procyclical movements in all three components. A problem arises empirically because there are no available measures for effort, $\phi$. We respond by choosing preferences so that effort per hour fluctuates with an elasticity of one half that of the workweek. This elasticity is based on time-motion studies in Britain that are reported in Schorr (1987). This is described more fully in the discussion of preferences.

We follow Deardoff and Stafford (1976) by distinguishing the effect on the capitallabor ratio of an increase in the number of workers from the effect of an increase in hours or effort of each worker. ${ }^{1}$ We assume that if a worker works longer hours per week or works at a more rapid physical pace the utilization rate of the capital he operates will also tend to increase:

$$
\mathrm{K}^{\prime}=(\phi \mathrm{H})^{\mu} \mathrm{K} \text {. }
$$

$\mathrm{K}$ denotes the capital stock; and $\mathrm{K}$, as before, is utilized or effective capital. We first set $\mu$ equal to zero; this yields a constant utilization rate for capital. We then set $\mu$ equal to one; this implies varying hours per worker and effort per hour has no impact on the capital labor ratio. The evidence discussed next is arguably consistent with this value. ${ }^{2}$ 
We turn now to evidence for our assumption that utilized capital increases significantly with hours per worker, but not with employment.

Since the 1950's the American Textile Manufacturers Institute has collected data on the workweek of looms in the cotton-textile weaving industry (published in Textile Hilights). We regress the workweek of looms on time series for production-worker employment and hours in cotton textiles. All three variables are in natural logs. The labor series are from the BLS establishment survey. Observations are quarterly for 1958 to 1985. Results are given in Table 1. In column one the relationship is estimated in levels, but with a correction for first-order autocorrelation in the residuals. In column two the relationship is estimated in first differences, but again correcting for autocorrelated residuals. The regressions also include time trends and seasonal dummies. Loom hours are strongly related to hours per worker. For both specifications, the elasticity with respect to hours per week is estimated at over .9 , and is insignificantly different from one. The coefficient on employment is also positive, but much smaller than for hours. This estimated relation is not causal in the sense of equation (3); firms may simply find it optimal to increase hours per worker and capital utilization at the same times. Nevertheless, it does support writing models in which capital utilization is closely related to hours per week.

It is desirable to have information on utilized capital beyond textiles. In lieu of such data, we examine electricity consumption in manufacturing. For electricity use to be a useful proxy for utilized capital requires that electricity and utilized capital be very complementary in production. (See Jorgenson and Griliches.) Columns 3 and 4 of Table 1 give results from regressing electricity use on employment and hours for a pooled sample of the 19 two-digit manufacturing industries. (Miscellaneous manufacturing is not included.). Data on electricity use are from the Annual Survey of Manufacturing for the 
years 1954 to 1985 . The specifications for columns 3 and 4 correspond respectively to those for columns 1 and 2 . In column 3 the data are in levels; but the autocorrelation parameter is estimated at one. There is a very strong relation between electricity use and hours per week, with a much weaker relation to employment. The coefficient on hours is actually greater than one, though insignificantly so. The coefficient on employment is significantly greater than zero but also significantly less than .30 . In column 4 the relation is estimated in first differences with a correction for autocorrelation. This considerably decreases the coefficient on hours and increases the coefficient on employment. Nevertheless, the coefficient on hours remains significantly larger than that for employment.

In sum, we find the evidence from textile looms and electricity supportive of modelling a close relation betweens hours per worker and utilized capital. We posit a relation of utilized capital to effort per hour as well.

Substituting for effective labor and capital inputs and rearranging yields a time series for technology, $\mathrm{Z}$.

$$
\begin{aligned}
\operatorname{Ln}\left(\mathrm{Z}_{\mathrm{t}}\right)= & \operatorname{Ln}\left(\mathrm{Y}_{\mathrm{t}}\right)-\theta\left[\operatorname{Ln}\left(\phi_{\mathrm{t}}\right)+\operatorname{Ln}\left(\mathrm{H}_{\mathrm{t}}\right)\right]-\alpha \operatorname{Ln}\left(\mathrm{N}_{\mathrm{t}}\right)-(1-\alpha) \operatorname{Ln}\left(\mathrm{K}_{\mathrm{t}}\right) \\
& \text { where } \theta=\alpha+\mu(1-\alpha) .
\end{aligned}
$$

We assume the technology disturbances follow a persistent $\operatorname{AR}(1)$ process:

$$
\operatorname{Ln}\left(Z_{t}\right)=p \operatorname{Ln}\left(Z_{t-1}\right)+\epsilon_{t}
$$

Most prior work examining real business cycles has ignored cyclical variations in utilization. In equation (4) this corresponds to setting $\theta$ equal to $\alpha$, and making $\phi_{\mathrm{t}}$ be a 
constant. We first calculated Solow residuals for this case, setting $\alpha$ equal to 0.64 . We then fit equation (5) to this time series (detrended). The result is given in the first column of Table 2. The estimated value for $p$ equals 0.95 . The standard deviation of the productivity innovations equals about three-fourth of one percent. The lower portion of the table examines the correlation of the Solow residuals with the cycle. Detrending (rows 4 and 5), we find a strong positive correlation between total factor productivity and real GNP, but little correlation between total factor productivity and aggregate hours (employment times hours per week). The last two rows relate quarterly rates of growth in Solow residuals to rates of growth in real GNP and aggregate hours. The conclusion is roughly similar to that from detrending. That productivity is positively correlated with output but not labor has been noted by others, for example Christiano and Eichenbaum (1988).

Columns 2 and 3 of Table 2 introduce procyclical utilization. In Column 2 we have changed the elasticity of output with respect to hours worked per week from 0.64 to 1.0 . This corresponds exactly to the case of no variations in effort, but capital utilization increasing proportionately with the workweek. Alternatively, it corresponds to a case of constant capital utilization, but effort varying with an elasticity equal to $36 / 64$ that of the workweek. This is quite close to the case we consider below. For the third column we set the elasticity of output with respect to hours per week equal 1.5. This corresponds to the most extreme case of procyclical factor utilization we consider--capital utilization proportional to the workweek and effort varying with an elasticity equal to one-half that for the workweek.

Not surprisingly, introducing procyclical factor utilization reduces the amplitude of the measured productivity disturbances and makes productivity appear less procyclical. For the 
case corresponding to Column 3, the observation of procyclical total factor productivity is largely eliminated. The negative relation between productivity and labor movements is nearly as strong as the positive relation to output movements.

The reduction in variability of the Solow residuals derives more from a reduction in the persistence of the innovations than from reduced variability of the innovations. This is particularly true for the stronger example of procyclical utilization in Column 3. Given that fluctuations in workweeks, $\mathrm{H}$, are much less persistent than fluctuations in output, it might appear surprising that removing procyclial utilization causes productivity residuals to become less persistent. However, the correlation between labor hours and the Solow residual becomes greater in absolute terms moving from Column 1 to Column 3--rather than being slightly negative, it becomes considerably negative. In the concluding section we return to the issue that Solow residuals are not actually positively correlated with hours of work.

In simulating our model economy we initially set the parameter $\rho$ equal to 0.95 , which is the value used in a number of earlier studies. We set the variance of output for our model to match the variance of real GNP for the postwar United States. We then ask if the variability of the implied technolgy shocks for the model economy are consistent with the time series evidence for the United States in Table 2. Based on the evidence in Columns 2 and 3, we also experiment with less persistent shocks to technology.

\section{Accumulation}

The net output from producing is allocated to consumption and augmenting the capital stock. We differ from most prior work, however, in defining net output. We net off not only depreciation on the capital stock, but also resources potentially needed to adjust the 
amount of capital matched with each worker. Capital accumulation is therefore described as follows.

$$
\mathrm{K}_{\mathrm{t}}=(1-\delta) \mathrm{K}_{\mathrm{t}-1}+\mathrm{Y}_{\mathrm{t}} \cdot \pi \mathrm{K}_{\mathrm{t}}\left[\left(\underline{\mathrm{K}}_{\mathrm{t}} \underline{\underline{N}}_{\mathrm{K}_{\mathrm{t}-1}-\mathrm{K}_{\mathrm{t}-1}} \mathbb{N}_{\mathrm{t}-1}\right)-\Phi\right]^{2}-\mathrm{C}_{\mathrm{t}} \cdot
$$

$\delta$ denotes the rate of capital depreciation; we choose an annual rate of 10 percent (Prescott, 1986). C denotes consumption. We assume quadratic costs of increasing capital per worker at a faster or slower rate than usual. $\Phi$ denotes the steady-state rate of growth in capital per worker. We have multiplied the adjustment cost by the size of the capital stock; so its importance will not decline over time for a growing economy .

Note that we model it as costly to adjust the amount of capital matched to each worker, as opposed to adjusting the capital-labor ratio. This distinction is necessary in our model to obtain hours per worker leading employment over the cycle. We also find it more intuitive. We have in mind that it is costly to switch the size of trucks that truckdrivers drive, or the quality of typewriter that typists use, or the number of individual stations on an assembly line.

We introduce costs of adjustment to generate hours leading and employment lagging the cycle. As an extremely related point, these costs generate realistic behavior for labor's share of income. For many years economists have noted the relative stability of labor's share. In U.S. data, however, there is a clear countercyclical pattern in labor's share: expansions are associated with transitory declines in labor's share, and the converse holds for recessions. Figure 1 displays labor share from 1947 to 1988 . Labor's share is defined as wages plus income of the self employed divided by GNP. Labor's share increased at the onset of each of the recessions of 1949, 1954, 1958, 1971, 1974-75, and 1980. There was no 
increase until the later stages of the severe 1982 recession.

Regressing the change in labor's share on the quarterly rate of growth in real GNP in the current and four preceding quarters yields:

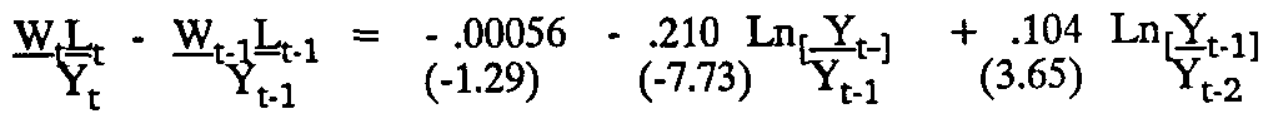

$$
\begin{aligned}
& +\underset{(1.78)}{.051} \operatorname{Ln}_{[} \underline{Y}_{t-2]}+\underset{(2.72)}{.077} \operatorname{Ln}_{Y_{t-3}} \underline{Y}_{t-3}+\underset{(0.86)}{.023} \operatorname{Ln}_{\left[-Y_{t-5}\right.}
\end{aligned}
$$

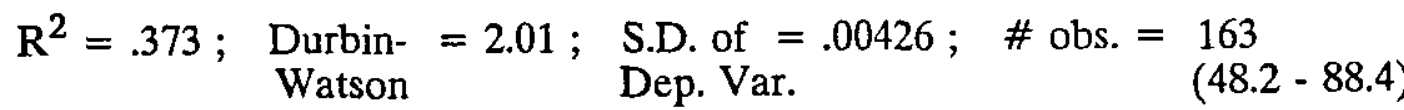

When GNP grows by 5 percent faster than normal, labor's share falls by about 1 percent in the first quarter. After the second quarter one half of this decline in labor's share is regained; and by the end of the fourth quarter all the decline is regained.

The costs of adjusting capital per worker in equation (6) are capable of generating this behavior. In an expansion firms employ less labor than suggested by equating the marginal product from the gross production function in equation (1) to the wage cost of a worker. Adding a worker is additionally costly because it further decreases an already decreased amount of capital matched to each worker. This additional cost to employment will cause labor's share to decline transitory. The marginal adjustment cost for employment will decline as the economy accumulates capital, restoring labor's share of output. ${ }^{3}$

There clearly are other possible explanations for cyclical variation in labor's share. If production is not Cobb-Douglas, labor's share will vary cyclically with the capital-labor ratio. For example, a C.E.S. production function with an elasticity of substitution of onehalf will generate a fall of about one percent in labor's share for an increase in labor hours 
of five percent. This is consistent with the coefficient of -0.21 on $Y_{t}$ in equation (7). But it would not predict the very rapid and strong rebound in labor's share depicted by Figure 1 and equation (7). A setting where wages are smoothed relative to variations in marginal product might generate this behavior. Suppose firms can only smooth wages for relatively short periods. Then a downturn might initially raise labor's share as wages remain high yet firms maintain workers as though the wage had adjusted downward. But if the downturn persists, it may not be feasible for firms to both maintain wage rates and employment. ${ }^{4}$ We prefer an explanation based on adjustment costs as there has been a good deal of empirical work supportive for a role for adjustment costs. Furthermore, the adjustment costs we assume are not large relative to most estimates in the literature (e.g. Pindyck and Rotemberg, 1983).

We use the cyclical behavior of labor share to guide our choice for the adjustment cost parameter $\pi$. Cost minimization requires a share for labor:

$$
\begin{aligned}
& \left.\underline{\mathrm{W}}_{\underline{\mathrm{Y}_{\mathrm{t}}}}=\alpha+\frac{2 \pi \mathrm{K}_{\mathrm{t}}}{\mathrm{Y}_{\mathrm{t}}}\left[\mathrm{Z}_{\mathrm{t}}-\mathrm{E}_{\mathrm{t}}\left\{\frac{\mathrm{K}_{\mathrm{t}}}{\left(1+\mathrm{r}_{\mathrm{t}}\right.}\right)_{\mathrm{t}}-\mathrm{Z}_{\mathrm{t}+1}\right\}\right] . \\
& \text { where: } \quad \mathrm{Z}_{\mathrm{t}}=\frac{\mathrm{K}_{t}}{\mathrm{~K}_{\mathrm{t}-1}} \underline{N}_{\mathrm{t}-1}-\left[\left(\underline{\mathrm{K}}_{\mathrm{t}} \mathbb{N}_{\mathrm{t}-\mathrm{K}}-\mathrm{K}_{\mathrm{t}-1} \mathbb{N}_{\mathrm{t}-1}\right)-\Phi\right]
\end{aligned}
$$

$\mathrm{W}$ denotes a weekly wage; $\mathrm{r}$ denotes a real interest rate. $\mathrm{E}_{\mathrm{t}}$ denotes an expectations operator conditioned on time $t$ information. We estimate this relation in first-differences with quarterly U.S. data for 1959 to $1988 .^{5}$ We instrument for the expectational component of the right-hand-side variable with rates of growth in employment, capital, and real GNP for periods $t$ and $t-1$, and the ex post real interest rate for periods $t-1$ and $t-2$. The resulting estimate for $\pi$ equals 0.00969 (with a standard error of 0.00258 ). This is the 
value we employ for $\pi$ in calibrating our model.

\section{Preferences}

A representative worker/consumer in our economy is assumed to maximize expected lifetime utility over an arbitrarily long lifetime:

$$
\begin{aligned}
& \operatorname{Max} \Omega=E_{\mathrm{t}} \stackrel{\sum}{\tau=\mathrm{t}}_{1+\mathrm{d}}^{\infty}\left(\frac{1}{1+\mathrm{t}} \mathrm{U}_{\tau}\left(\mathrm{C}_{\tau}, \mathrm{N}_{\tau}, \mathrm{H}_{\tau}, \phi_{\tau}\right)\right. \\
& \text { where: } \mathrm{U}_{\tau}\left(\mathrm{C}_{\tau}, \mathrm{N}_{\tau}, \mathrm{H}_{\tau}, \phi_{\tau}\right)=\mathrm{A}_{\tau} \operatorname{Ln}\left(\mathrm{C}_{\tau}\right)-\mathrm{V}\left(\mathrm{N}_{\tau}, \mathrm{H}_{\tau}, \phi_{\tau}\right) .
\end{aligned}
$$

Consumption enters favorably in utility and all three labor variables enter negatively. We assume time-separable preferences. $d$ is the rate of time preference; we follow Kydland and Prescott in assuming an annual rate of time preference of 4 percent. We further assume the utility function, $\mathrm{U}()$, is separable in consumption and leisure (labor), and that utility is a natural log function of consumption. Previous authors have defended this assumption by claiming there is little secular trend in hours of market work per person. The term $\mathrm{A}_{\tau}$ allows preference shifts that affect aggregate consumption demand.

We make no distinction between individuals who work and do not work. The variable $\mathrm{N}_{\tau}$ is best interpreted as weeks at work during period $\tau$, which are common to all persons. Actual movements in employment can be interpreted as the sum of two components: changes in labor force participation and changes in the fraction of weeks that workers in the labor force are at work (i.e. changes in the unemployment rate). We are focusing on the latter component. By focusing on changes in employment rates we can abstract from how workers and nonworkers differ in compensation and consumption in a competitive 
equilibrium. $^{6}$

Empirically movements in employment rates for a given workforce are cyclically at least as important as movements in labor force participation. Hall and Lillien (1986, Table 1) show that for the years 1956 to 1983 changes in the unemployment rate contributed 70 percent of the movement in total employment, whereas changes in labor force participation contributed only 30 percent. $^{7}$

To provide addition evidence we examined the relation:

$$
\begin{gathered}
\text { Average } \\
\operatorname{Ln}(\text { Employment })
\end{gathered}=\underset{\begin{array}{c}
\% \\
\text { work at all }
\end{array}}{\operatorname{Ln}(\text { population who })}+\begin{gathered}
\text { Employment } \\
\operatorname{Ln}(\text { rate for all who }) \\
\text { work }
\end{gathered} .
$$

These classifications are less subjective than are unemployed versus out of the labor force. Data on the number of persons who were employed at all during a given year are drawn from the Current Population Surveys. To be consistent with this source, we use here the BLS employment series constructed from this household survey. The average employment rate is then found by dividing employment by the fraction who ever worked in the year. To guage the relative contributions of the two components in equation (11), we regressed each component on annual employment for the years 1950 to 1983 . All variables are relative to noninstitutionalized population and are detrended. We find that a one percent deviation from trend in employment on average resulted from a .20 percent change in the fraction of individuals who worked during the year and a .80 percent change in weeks at work during the year for a given sized workforce. (The standard error on these estimated shares equals 0.12 . $)^{8}$ So changes in weeks for a given labor force is easily the more important component.

We turn now to describing the disutility of working. We specify that: 


$$
\mathrm{V}(\mathrm{N}, \mathrm{H}, \phi)=\left(\frac{\mathrm{a}}{1+\sigma}\right) \mathrm{N}^{1+\sigma}+\left(\frac{\mathrm{b}}{1+\mathrm{B}}\right) \mathrm{NH}^{1+\mathrm{B}}+\left(\frac{1}{1+\tau}\right) \mathrm{NH} \phi^{1+\tau} .
$$

The first component represents costs of being at work a fraction $\mathrm{N}$ of the weeks in a period, even if hours are arbitrarily small. This term guarantees that workers do not typically choose to work 52 weeks of the year. Rogerson (1988) and others have focused on fixed costs of going to work, such as commuting or hiring a baby sitter in rationalizing such a term. Fixed costs of enjoying leisure, however, are possibly equally important. For example, a worker in New Hampshire would be less likely to choose stretches of days away from work if Disney World were not a twenty hour drive away. The second term reflects disutility of being at work, rather than some best alternative, even when exerting no productive effort. The marginal disutility of spending time at work rises with the fraction of the week spent at work. The third term reflects disutility from exerting effort. The marginal disutility of effort rises with the level of effort.

This specification is capable of generating responses in all three labor margins. Small values for $\sigma, B$, and $\tau$ are associated with relatively large responses in employment, hours, and effort respectively. An infinite value for $\tau$ implies no movements in effort, as is typically assumed. A value of zero for $\sigma$ generates a model with only movements in weeks worked per year. An infinite value for B also yields a constant workweek; however, it remains possible to have movements in effort as well as employment.

We must choose parameter values for $\sigma, B$, and $\tau$. We turn first to the parameter $B$, which dictates the responsiveness of the workweek. This parameter is key in determining the elasticity of aggregate labor supply because, as discussed momentarily, we tie our choices for the parameters $\sigma$ and $\tau$ to $B$. We choose a value for $B$ of two; this implies a compensated hours per week supply elasticity of 0.5 . Prescott (1986) assumes a 
compensated elasticity of labor supply of 2.0. In his model, however, this elasticity must capture labor movements in the form of both employment and hours. An elasticity of 2.0 is probably far too high for the response of workweeks. We know of no micro labor study that finds responses in hours per week for employed persons that display elasticities above 0.5. (Pencavel, 1986, and Killingsworth and Heckman, 1986, survey much of this evidence.) If workers are unconstrained in their choice of hours per week, then Bils (1987) calculates that the elasticity of marginal overtime pay with respect to hours requires an hours-perweek supply elasticity of about 0.7 .

Abstracting from adjustment costs, the preferences in equation (11) dictate a response in weeks worked, $\mathrm{N}$, that is $(1+B) / \sigma$ times the response in hours per week, $\mathrm{H}$. (With adjustment costs employment fluctuates relatively less. But for adjustment costs of the magnitude we entertain in our simulations the relative volatility of employment is only reduced, from Table 5, by about one-tenth.) Given the magnitude of the parameter $B$, the size of the parameter $\sigma$ can be determined from knowledge of how workers choose to respond in weeks and hours to a change in demand for their labor.

To estimate these relative responses, we examine cross-sectional data on the relative size of individual changes in weeks and hours. We use 17 consecutive years (waves 1971 to 1987) of the Michigan Panel Study of Income Dynamics (PSID). We use cross-sectional standard deviations in these changes in order to abstract from the business cycle. This makes the evidence for choosing $\sigma$ independent of the aggregate time-series we wish to explain. The sample includes heads of households and spouses who worked at any point in each of two consecutive years. Results are presented by year in Table 3. The standard deviation of changes in weeks relative to that for changes in hours is fairly consistent across years, varying between 1.40 and 1.73 . It averages 1.54 . 
We suspect this understates the true relative variability of changes in weeks worked because reporting errors are probably more prevalent in hours per week, and add to the measured variability of its changes. Duncan and Hill (1985) investigate reporting error for the PSID by asking PSID questions to workers at a large company and comparing their responses to company records on hours and earnings by worker. They find that the interview responses accurately depicted workers' changes in weeks of work. The survey responses to change in work hours, however, exaggerated variability by 24 percent (Table 2 , page 516). On this basis, we increase the estimate of relative weeks to hours variability by 24 percent, from 1.54 to 1.91 . This is the value we use for the parameter combination $(1+B) / \sigma$. Given our value for $\beta$ of two, this requires a value for $\sigma$ of 1.57 .

The most difficult preference parameter to judge is $\tau$, which dictates the willingness of workers to vary rate of effort at the job. The model economy exhibits an elasticity of effort with respect to the workweek of $B /(1+\tau)$. Initially, we make $\tau$ infinite, so that effort levels are constant, as is usually assumed. We base a second value for $\tau$ on analysis of timemotion data.

Schor (1987) reports a time-series for physical activity at work for a large number of workers in British manufacturing for the years 1970 to 1986 . The following description of the data is distilled from her paper. "The percentage utilisation of labour (hereafter PUL) index measures the actual work intensity of 131,500 direct operatives (i.e. machine-tenders) in a statistically-representative standing panel of $\mathbf{1 7 1}$ factories in the manufacturing sector of Great Britain. ...... The PUL is based on the relationship between actual effort and a pre-defined standard level of intensity. The standard is calculated by Work Measurement Personnel (colloquially known as "time and motion" men). At the time a work task is created, the Work Measurement Personnel allocate it a number of 'standard seconds'." 
Schor reports a regression of effort (the PUL) on hours per week in British manufacturing as well as some additional variables. Over five specifications the estimated elasticity of the effort index with respect to the workweek ranges from 0.516 to 0.597 . (Standard errors in all cases are about 0.14 ). We choose a value for the elasticity to incorporate in our model economy of 0.5 , which is slightly conservative relative to Schor's estimates. For the ratio $B /(1+\tau)$ to equal one half, given $B$ equal to two, requires a value for $\tau$ of 3 .

\section{Steady-Growth Solution}

We calculate the steady-growth path for the economy just described. (That is, time series for a constant rate of growth in the technology parameter $Z$.) We then simulate business cycles by approximating decision rules around this path. Our model economy contains no distortions or externalities. We therefore calculate competitive equilibrium from the solution to a social planner's problem of maximizing utility for a representative worker/consumer.

In comparison with most real-business cycle exercises, this additionally assumes that the labor market produces separate optimal choices for employment, hours, and effort. It is possible to envision several ways that a competitive labor market might produce these choices. Employers could set an appropriate price for output or effective units of labor, then allow workers to freely choose weeks of work, hours per week, and effort level. This might resemble certain piece-rate systems. Alternatively, workers could present employers with a wage bill that takes the form of $\mathrm{V}(\mathrm{N}, \mathrm{H}, \phi)$ and allow firms to freely choose weeks, hours, and effort. For hourly workers the wage-bill is explicitly tied to the workweek and the wage rate in fact increases with $\mathrm{H}$ through shifting from straight-time to overtime rates. We do not see the same explicit link of compensation to effort except through piece-rates. 
If wages are flexible it is not necessary for employers to face an explicit cost for increasing hours or effort. By offering the optimal package of weeks, hours per week, and effort employers will attract effective labor input at the minimum cost in total wage bill. The concluding section discusses the impact of wage rigidities. If wage payments are cyclically rigid this might limit the ability of employers to vary effort procyclically because it might create excessive quits. If so, the estimates of cyclical effort movements Schor finds might exaggerate the cyclicality of effort for the U.S. economy. Schor's estimates are based on a sample of piece-rate workers; therefore there is some increase in wages in response to increased effort.

A dynamic first order condition for investment requires that the marginal utility of consuming today be equated to the output value of a unit of capital times the marginal utility of consumption tomorrow. (On the steady growth path costs of adjustment are zero. $)^{7}$ Along a steady-growth path, all three labor variables are constant. The capital stock, output, and consumption all grow at the same rate of $(1 / \alpha)$ times the steady rate of growth in $\mathbf{Z}^{\mathbf{8}}$

\section{Results for Fluctuations}

Table 4 contains summary statistics for U.S. quarterly time series for mid 1955 to early 1984. ${ }^{11}$ (The data are detrended using the Hodrick-Prescott filter; time-series simulated for model economies are similarly detrended.) The ratio of the standard deviations of aggregate hours and labor productivity has been empasized in the literature as a measure 
of a model economy's goodness of fit. (See Kydland and Prescott, Hansen, 1985, and Cho, 1990). It is 1.47 for the U.S. data. Our model has movements in hours per worker, employment, and effort. The table shows that employment (bodies) fluctuate three times more than hours per worker. Unfortunately, no time series is available on effort per hour. Recently the correlation structure has received more attention because some of the correlations are very difficult for the model economies to mimic, especially the correlations of labor productivity (output per aggregate hour of labor) with output and with aggregate hours. (See Christiano and Eichenbaum, 1989.) The former is .35 and the latter, which is not reported in the table, equals -.20. (Also see Table 3 for correlations of total factor productivity with the cycle.)

The preceding section incorporated costs of adjustment and time-varying factor utilization into a real-business-cycle model. Tables 5 to 7 report the means of the statistics for 100 simulations for a series of models gradually bringing in these features. Table 5(A) reports statistics for a benchmark case without varying capital or labor utilization and without costs of adjustment, but with all other parameters taking values as discussed above. The model cannot mimic observed output variability with reasonable variations in technology. We need to set the standard deviation of the technology shock to .01 to obtain output fluctuations with the magnitude observed for the U.S. economy. These appear unreasonably large. Prescott (1986) suggests the plausible range of the size of such shocks as .007 to .009 ; Table 2 suggests a value on the order of .0075 . The failure of this benchmark model is apparent in other dimensions. Fluctuations in hours per week and in employment are both too small, whereas those in productivity are too high. The relative volatility of employment to hours is about two, which is smaller than for the U.S. economy. In addition, correlations with output of hours per week, employment, and total hours are 
all too high for the model. The correlation of labor productivity with output is far higher for the model than for U.S. data.

One reason for the poor performance of our benchmark model is that, distinct from other papers, we are using a much smaller, and we believe more realistic, intertemporal elasticity of labor supply. The compensated labor supply elasticity for hours per week and employment combined for our model equals 1.4. Increasing the elasticity of labor supply would improve the performance of the model by increasing volatility of hours and output.

Although we do not model these features here, there are several ways to reconcile high volatility of hours and output with a relatively low intertemporal elasticity of labor supply. We could introduce additional shocks such as government spending or preference shocks (as, respectively, in Christiano and Eichenbaum and Stockman and Tesar, 1990).

Alternatively, real wage or price rigidities might be introduced. It is well known that a real wage rigidity magnifies the impact of technology shocks considerably. Thirdly, monetary shocks, in conjunction with nominal wage or price rigidities might be introduced. Cho (1990), Cho and Cooley (1990), and King (1990) suggest that nominal rigidities may be crucial missing elements in the real business cycle story. The concluding section returns to these issues.

Table 5(B) reports the effects of introducing costs of adjusting the employment-capital ratio. The adjustment costs reduce the volatility of employment by 6 percent and increase that of workweeks by about 4 percent. The ratio of the standard deviation of employment to that of hours per week is reduced by 10 percent (a ratio that was already too small for the model economies compared to U.S. data). The variability of total hours is reduced by about 5 percent. With adjustment costs, the model requires 2 percent larger flucturations 
in technology to generate the same output volatility.

The impact of adding effort movements is reported in Table 6(A). The impact is notable, though not extremely large. The required variability of the technology shocks to produce the same volatility of output as for the U.S. economy is reduced by 9 percent (to 0.95 percent); thus the economy responds somewhat more vigorously to shocks. Burnside, Eichenbaum, and Rebelo (1990) examine a model, like Table 6(A), with variations in effort, but not in the utilization rate of capital. They attach a much greater importance to variations in effort; but we believe they employ an implausibly large intertemporal elasticity of substitution in workers' rates of effort.

The impact of procyclical capital utilization, as well as effort, is presented in Table 6(B). Procyclical utilization makes it possible to reduce the variability of the technology shock by 21 percent (to 0.83 percent) and yet observe the same amount of variability in output. The variability of the technology shock is now within the range of values suggested by Prescott (1986). However, it is crucial to keep in mind that allowing varying utilization dramatically reduces variability of Solow residuals calculated on U.S. data (e.g., Table 2, row 3). In other words, the measured variability of technology shocks by Prescott will be overstated. $^{12}$

The results in Table 2 suggest that introducing procyclical labor and capital utilization considerably reduces the persistence and unconditional variance of the productivity residuals are considerably reduced. Therefore, we resimulated the model with adjustment costs and procyclical effort and capital utilization changing the $\operatorname{AR}(1)$ parameter of the technology shocks from 0.95 to 0.85 . The results are reported in Table 7. Comparing to Table 6(B), we find the following. As the technology shocks become less permanent the impact of the disturbances on permanent income and consumption lessens dramatically. 
The variability of consumption relative to that of investment spending decreases by 39 percent. As consumption becomes more stable, labor supply becomes considerably more responsive to disturbances. There is now much less of a stabilizing influence on labor supply from decreasing marginal utility of consumption in booms. The variability of total hours relative to that in labor productivity increases by 25 percent.

Adjustment costs are particularly important when disturbances are relatively temporary. In Table 7 the variability of hours per worker is 73 percent as large as for employment. (This result is quite counterfactual.) Because variations in utilization are proportional to variations in the workweek, effort and capital utilization movements become more important with the less persistent shocks. The greater responsiveness in total hours, effort, and capital utilization implies the potential of explaining output movements with less variability in the technology. The standard error for technology $\left(\mathrm{Z}_{\mathrm{t}}\right)$ in the Table 7 case equals 1.47 percent compared to 2.66 percent for Table 6(B) (and 3.27 percent for Table 5(A)). This variability is very close to that suggested by the examination of Solow residuals in Table 2, Column 3. Nevertheless, the correlations between productivity and output and between productivity and total labor hours remain very high; and this is very inconsistent with the data.

Figure 2(A) shows the impulse responses in output, consumpton, and investment to a one percent positive realization for the technology shock. These responses are for the model simulated in Table 7. The initial response of the economy is nearly a two percent expansion in output driven largely by a sharp increase in investment. Figures 2(B) and 2(C) show the responses in total labor hours and the capital stock respectively. Labor hours increase by three quarters of a percent initially. The expansion in labor is virtually ended by the 16th quarter of an expansion. After 16 quarters the expansion in the capital 
stock, by contrast, nearly peaks. Figure 2(D) displays the behavior of labor productivity. Without procyclical capital utilization and effort, labor productivity would increase by less than one percent initially because of the decrease in the capital-labor ratio. But for our model labor productivity initially goes up by a little more than one percent. Productivity stays above trend for some time because of the build-up that occurs in capital.

Figure 3 provides detailed short-run (up to 2 years) responses in labor variables and labor productivity. Dashed lines correspond to the model presented in Table 7. To illustrate the role of adjustment costs, the figures include solid lines corresponding to the same model, but without costs of adjustment. The adjustment costs cut the first quarter response in employment by over 40 percent (Figure $3(C)$ ). The adjustment costs reduce the response in total hours and output considerably during the first two quarters of an expansion (Figure 3(A)), even though they have a small impact on sample variability for these variables.

The peak responses are all synchronized without adjustment costs; but with these costs they differ considerably. Employment does not peak until the second or third quarter of an expansion. We believe this result to be quite consistent with U.S. time series for employment. We define hoarded labor by the difference in employment with and without adjustment costs. As shown in Figure 3(E), movements in hoarded labor are an important countercyclical force in the early stages of cycles. Workweeks rise significantly at the onset of an expansion (Figure 3(B)), partly in response to costs of adjusting bodies. Together these figures show that workweeks clearly lead employment over the cycle. This is one empirical observation we required of our model. If we define the cycle by output movements, we would conclude that workweeks lead the cycle and employment lags the cycle. Effort and capital utilization are perfectly correlated with the workweek. The large 
response in hours per worker at the beginning of an expansion translates to an important increase in factor utilization (Figure $3(\mathrm{D})$ ). Consequently, productivity strongly leads the business cycle. This is another empirical observation we required of our model.

\section{Conclusions and Extensions}

We have introduced procyclical labor and capital utilization as well as costs of rapidly increasing employment into a business cycle model. We believe we have introduced plausible magnitudes for each of these aspects. Much of the paper has focused on our choices for these magnitudes.

Our primary conclusions are as follows. By adding plausible cyclical variations in labor and capital utilization, we can generate the same amount of aggregate output variability with about 21 percent smaller technology disturbances when these disturbances are quite persistent (autocorrelation of 0.95 ). Variations in factor utilization become considerably more important for disturbances that are less persistent. The costs of adjustment also create very interesting and realistic lead and lag relationships. We find that employment expands much less initially to disturbances; and employment's response does not peak until the end of the second quarter of an expansion. Workweeks, effort, capital utilization, and productivity all sharply lead the business cycle.

Nevertheless, our simulated business cycles dramatically differ from observed cycles. Most importantly, total labor hours are far more procyclical, labor productivity is far more acyclical, and the correlation between labor hours and labor productivity is very much 
closer to zero in observed cycles compared to our simulations. We end by considering possible extensions that could generate cycles with stronger cyclical movements in labor hours, and much weaker movements in labor productivity. We are particularly concerned with how such extensions might alter our picture of the qualitative impact of adjustment costs for employment and procyclical factor utilization.

Consider the static first-order condition that the marginal disutility of working one more hour equal its marginal product times the marginal utility of consumption. For our model this condition can be written (solving first for optimal effort):

$$
\operatorname{Ln}\left(\mathrm{H}_{\mathrm{t}}\right)=\text { Constant }+(1 / \beta)\left[\operatorname{Ln}\left(\frac{\mathrm{Y}_{t}}{\mathrm{~N}_{\mathrm{t}} \mathrm{H}_{\mathrm{t}}}\right)-\operatorname{Ln}\left(\mathrm{C}_{\mathrm{t}}\right)\right]
$$

where $(1 / \beta)$ equals the compensated labor supply elasticity for hours per week. To observe important cyclical movements in workweeks, as we do, requires that labor productivity be considerably more procyclical than consumption or that the elasticity of hours per week be large. We believe this labor supply elasticity is relatively small. (We set it equal to 0.5 above.) But regardless, there is the larger empirical problem that consumption is much more procyclical than labor productivity. Regressing the log of hours per week on the log of labor productivity minus the log of consumption with quarterly U.S. data for 1948 to 1985 (with linear and quadratic trend terms) yields a negative coefficient of -0.115 with a standard error of -0.0016 . (In more detail, the estimated elasticity of labor productivity with respect to hours per week is 0.474 with standard error 0.093 , whereas the estimated elasticity of consumption is 2.683 with standard error 0.353 .)

Several possible resolutions come to mind. ${ }^{13}$ One is to allow preference shocks, thereby adding a procyclical disturbance to equation (12). Stockman and Tesar, for 
instance, allow disturbances to the marginal utility of consuming. We introduced such disturbances into our model by allowing the multiplicative term, A, on utility from consuming in equation (9) to be stochastic. The right-hand-side of equation (12) then has the added term $(1 / \beta) \operatorname{Ln}\left(A_{t}\right)$ as a source for movements in hours worked. These consumption demand shocks also help empirically by increasing the variability of consumption. Recalling Table 7, with less persistent shocks, the relative variability of consumption to variability of investment is much lower than in U.S. time series.

We assume the preference term $A_{t}$, like the technology term, follows an $\operatorname{AR}(1)$ process. We assume the preference and technology shocks are uncorrelated. We choose the variability of innovations to make the relative variabilities for consumption and investment for the model equal the observed value from Table 4 of 0.153 . We set the $\mathrm{AR}$ (1) parameter to 0.94 . We based this value on the first-order autocorrelation of errors to equation (12); these errors theoretically are proportional to $\operatorname{Ln}\left(A_{t}\right)$.

Results for a simulated model with both technology and preference disturbances are given in Table 8. With the exception of the preference shocks, all parameters are identical to the model of Table 7. Comparing Tables 7 and 8, variability of total hours is increased by about 13 percent with the addition of the preference shocks. The correlation between output and hours is reduced from 0.98 to 0.95 ; and the correlation between output and labor productivity is reduced from 0.99 to 0.96 . Both correlations, however, remain very far above those observed in U.S. data. With preference shocks, it is possible to reduce the magnitude of the technology shocks and achieve the same output variability; but it is possible to reduce technology shocks by only 2.5 percent. Though preferences are quite variable relative to technology, technology shocks remain dominant as a source of output fluctuations. 
Figure 4 presents impulse responses to a positive one percent preference shock. Figure 4(A) shows that the resulting increase in consumer spending is largely offset by a short-run reduction in investment spending. This is presumably why technology shocks remain the dominant source of output fluctuations for this economy. Figures 4(B) through 4(D) display long-run responses in total labor hours, the capital stock, and labor productivity. Figure $4(\mathrm{E})$ shows the short-run response in the labor quantities. Similarly to the technology-shock case, employment and total hours do not peak until the second quarter of the expansion. Hours and effort lead the cycle, and particularly lead employment. Labor productivity initially increases slightly thanks to the increases in effort and capital utilization. It soon decreases below zero, however, due to reduced capital per worker. All movements in labor productivity are quite small. We believe our model again generates realistic lead-lag relationships between variables, with workweeks and productivity leading expansions, and employment lagging.

Disturbances to the marginal utility of consuming face their own empirical difficulty: They cause the market real interest rate, which is already procyclical (see the growth rate of consumption in Figure 2(A)), to become even more procyclical. This is a problem as measured expected real interest rates are acyclical. Alternatively, we could entertain disturbances to the marginal disutility of supplying labor. This would make market real interest rates less, rather than more, procyclical. If such disturbances were common across all labor terms (i.e., a multiplicative term on the $V()$ function in equation (11)), then the various labor margins would again be commonly affected; and we suggest our conclusions remain relevant. On the other hand, if the labor supply disturbances apply differently for bodies, hours, or effort, then the importance of relative movements in these labor margins will be altered; and the importance of adjustment costs and cyclical factor utilization will be 
altered.

Another alternative would be to introduce materials or energy price disturbances. A fall in the price of imported oil used in combination with labor in producing could increase the marginal net revenue product of labor, without affecting the average productivity of labor. Thus this could provide a procyclical disturbance to equation (12). Presumably such disturbances would not alter the relative costs or benefits of the three labor margins; therefore we anticipate that our analysis of procyclical factor utilization would be relevant.

Finally, it is possible to introduce wage and/or price rigidities. There is a large literature on wage rigidities that allow the potential for workers to be moved off their labor supply schedules. This can create a procyclical disturbance in equation (12). If compensation were equally rigid with respect to all labor margins then we would claim our results are still quite relevant. It is reasonable, however, to expect compensation to be most rigid with respect to effort, most flexible with respect to hours per week, with responsiveness to employment in between. Output price rigidities can generate important movements in the marginal revenue product of labor relative to its marginal physical product, thereby creating a potential procyclical disturbance for equation (12). This has been shown for general disequilibrium models as well as for market-clearing models with countercyclical price markups (e.g., Bils 1991). This effect should not alter the relative merits of the various labor components. Therefore it should not jeopardize our modeling of the relative importance of cyclical utilization. 


\section{Footnotes}

1. Lucas (1970), Deardoff and Stafford (1976), and Shapiro (1986) have each stressed the impact on capital utilization when workers are added through additional shifts. We ignore the issue of shifts. We also abstract from any user cost of capital--firms choose to utilize capital less than 100 percent of the time because it is costly to work labor around the clock, not because of a user cost of capital.

2. To maximize profits, firms set the relative marginal products of hours per worker and number of workers to their relative costs. Let $\mathrm{W}(\mathrm{H})$ denote the compensation paid to workers working $\mathrm{H}$ hours per week. Profit maximization requires:

$$
1+\mu(1-\alpha) / \alpha=\frac{\mathrm{W}^{\prime}(\mathrm{H})}{\mathrm{W}(\mathrm{H}) / \mathrm{H}} \text {. }
$$

Suppose momentarily that all workers typically work 40 hours per week and that an overtime premium of 50 percent is required to work workers above 40 hours. This might suggest a marginal wage, $W^{\prime}(H)$, equal to 1.5 times the average wage. Substituting a value of two thirds for $\alpha$, this implies a value for $\mu$ of exactly one. But this probably overstates the marginal wage relative to the average wage. Some fringe expenses and some payroll taxes increase more for an increase in employment, than for an increase in hours per worker. Secondly, many workers do not receive overtime pay for an increase in hours because their hours are below 40 or because they are not covered by overtime.

3. Alternatively, we could entertain costs of adjusting employment created by training or hiring and firing costs (Oi, 1962). Hansen and Sargent (1988) consider employment adjustment costs in a real-business-cycle model. Such costs cause hours per worker to lead the cycle and employment to lag. They can also generate the cyclical pattern in labor's share described above. Training costs are appealing if the variations in aggregate employment occur primarily through persons entering and exiting the workforce. As we discuss in the following section, however, changes in weeks worked for a given workforce are cyclically more important than changes in labor force participation. A technical problem with training or hiring and firing costs is that it creates a heterogeneous population. This complicates how consumption will be allocated across persons in a competitive equilibrium (Grilli and Rogerson, 1986). 
4. Price rigidities or systematic variation in price-marginal cost margins can also cause variations in labor share. Bils's (1987) results imply that countercyclical price markups cause cyclical movements in labor share to understate the magnitude of adjustment costs. 5. A capital stock figure is generated by, setting this quarter's capital stock equal to last quarter's plus gross investment minus depreciation; constant dollar values for quarterly investment and depreciation are from the National Income Accounts. This generated series is indexed to equal twelve trillion for the end of 1990 . This 1990 value is based on calculations from BLS data reported by Auerbach and Kotlikoff (1992). The real interest rate is derived from the one-year treasury bill rate and the rate of inflation for the GNP deflator. As before, $\mathrm{Y}$ is measured by real GNP; and $\mathrm{N}$ is measured by total nonagricultural employment as reported by the BLS.

6. Rogerson (1988) considers employment lotteries for achieving first-best employment and consumption allocations; but such lotteries may be subject to incentive problems if they yield lower utility for workers than nonworkers (Grilli and Rogerson, 1986).

7. We calculate this from their tables by taking the sum of the absolute deviations from trend for the unemployment rate and comparing to the sum of the absolute deviations from trend for the participation rate.

8. This assumes that persons entering and exiting the workforce work approximately as many weeks per year as those steadily in the workforce. If those entering average fewer weeks, then this overstates the importance of changes in labor force participation.

9. This condition yields:

$$
\mathrm{K}^{*}=\left(\frac{1-\alpha}{d+\delta}\right)^{1 / \alpha} \mathrm{Z}^{1 / \alpha}(\phi \mathrm{H})^{\theta / \alpha} \mathrm{N}
$$

For $\mu$ greater than zero the power on $(\phi \mathrm{H})$ is greater than one.

10. Combining equation (ii) with the static first-order conditions for employment, hours, and effort yields labor values:

$$
\begin{aligned}
& \mathrm{N}=\left[\left(\frac{\mathrm{d}+\delta}{\mathrm{d}+\mathrm{d} \delta}\right) \theta\right]^{\mu} c_{1}^{-\mu \tau} c_{2}^{-\mu(\beta \tau+1+\tau) /(1+\tau)}, \\
& \mathrm{H}=\mathrm{c}_{2} \mathrm{~N}^{\gamma /(1+\beta)} \\
& \phi=\mathrm{c}_{1} \mathrm{H}^{\beta /(1+\tau)}
\end{aligned}
$$




$$
\text { where: } \begin{aligned}
c_{1} & =[(1+\tau) \mathrm{b} / \tau]^{1 /(1+\tau)} \\
c_{2} & =((\mathrm{b} / \mathrm{a})[\beta /(1+\beta)-(1-\alpha / \theta)(1+1 / \tau)])^{-1 /(1+\beta)} \\
\mu & =\frac{1}{1+\gamma^{\prime} \frac{\beta \gamma}{(1+\beta)(1+\tau)}} .
\end{aligned}
$$

For employment, hours, and effort to achieve interior solutions requires that the term $B /(1+B)-(1-\alpha / \theta)(1+1 / \tau)$ be greater than zero. This is true for the range of parameters we consider.

Combining these equations with equation (ii) and the production function, one can show that the capital stock, output, and consumption all grow at $(1 / \alpha)$ times the rate of growth in Z. King, Plosser, and Rebelo (1988) discuss transforming a growth path to a stationary equilibrium by dividing certain time series by a measure of trending technology. For our model this term is $\mathrm{Z}_{\mathrm{t}}^{1 / \alpha}$.

11. The source for the nonlabor series is the National Income and Product Accounts; the labor series come from the Bureau of Labor Statistics.

12. Kydland and Prescott (1988) calculate a larger impact of variations in capital utilization. We believe there are two reasons for this. One, they allow capital utilization to increase with all changes in labor hours, whereas we view only increases in workweeks as increasing the utilization rate of capital. This is important because the brunt of hours variations are through varying employment. Secondly, they assume a much larger elasticity of supply for total labor hours of about 4, compared to our value of 1.4 .

13. Notice that, as equation (12) expresses movements in the workweek, introducing indivisible labor (e.g., Rogerson) does not overcome this problem. (It does lessen the magnitude of procyclical movements in the workweek.) Introducing disturbances in government spending or in investment spending behavior theoretically helps generate movements in hours by reducing the procyclicality of consumption in this relation. But it does not help explain the puzzle of very procyclical hours in conjunction with consumption being much more procyclical than labor productivity.

One possibility, which we neglect in the text, is that the marginal product of labor is more procyclical than its average product. Lower quality workers entering the workforce in booms could have this effect (see, for example, Hansen, 1985, and Cho, 1992). 


\section{$\underline{\text { References }}$}

Bils, Mark, 1987, The cyclical behavior of marginal cost and price, American Economic Review 77, 838-855.

Bils, Mark, 1991, Cyclical pricing of durable goods, Mimeo (University of Chicago, Chicago, IL).

Burnside, Craig, Martin Eichenbaum, and Sergio T. Rebelo, 1990, Labor hoarding and the business cycle, NBER Working Paper no. 3556.

Cho, Jang-Ok, 1992, Heterogeneous agents and the business cycle, Mimeo (Queens University).

Cho, Jang-Ok, and Richard Rogerson, 1987, Risk sharing, indivisible labor, and aggregate fluctuations, Mimeo (University of Rochester, Rochester, NY).

Cho, Jang-Ok, and Thomas Cooley, 1988, Employment and hours over the business cycle, RCER working paper no. 132.

Christiano, Larry J., and Martin Eichenbaum, 1988, Is theory really ahead of measurement, NBER Working Paper no. 2700.

Deardorff, Alan, and Frank Stafford, 1976, Compensation of cooperating factors, American Economic Review 66.

Duncan, Greg, and Daniel Hill, 1985, An investigation of the extent and consequences of measurement error in labor-economic survey data, Journal of Labor Economics 4, 508-532.

Grilli, Vittorio, and Richard Rogerson, 1986, Indivisible labor, experience and intertemporal allocations, Mimeo (University of Rochester, Rochester, NY).

Hall, Robert E., and David M. Lilien, 1986, Cyclical fluctuations in the labor market, In O. Ashenfelter and R. Layard, eds., The handbook of labor economics, Vol. 1 (North Holland, Amsterdam).

Hansen, Gary D., 1985, Indivisible labor and the business cycle, Journal of Monetary Economics 16, 309-327.

Hansen, Gary D., and Thomas J. Sargent, 1988, Straight time and overtime in equilibrium, Journal of Monetary Economics 21, 343-360.

Jorgenson, Dale W., and Zvi Griliches, 1967, The explanation of productivity change, 
Review of Economic Studies 34, 249-283.

Killingsworth, Mark, and James J. Heckman, 1986, Female labor supply: A survey, In O. Ashenfelter and R. Layard, eds., The handbook of labor economics, Vol. 1 (North Holland, Amsterdam).

King, Robert G., Charles I. Plosser, and Sergio T. Rebelo, 1988, Production, growth, and business cycles I, Journal of Monetary Economics 21, 343-360.

Kydland, Fynn E., and Edward C. Prescott, 1982, Time to build and aggregate fluctuations, Econometrica 50, 1345-1370.

Kydland, Fynn E., and Edward C. Prescott, 1988, The workweek of capital and its cyclical implications, Journal of Monetary Economics 21, 343-360.

Kydland, Fynn E., and Edward C. Prescott, 1990, Business cycles: Real facts and a monetary myth, Federal Reserve Bank of Minneapolis Quarterly Review, 3-18.

Lucas, Robert E., 1970, Capacity, overtime, and empirical production functions, American Economic Review 60, 23-27.

Oi, Walter Y., 1962, Labor as a quasi-fixed factor, Journal of Political Economy 70, 538-555.

Pencavel, John, 1986, Labor supply of men: A survey." In O. Ashenfelter and R. Layard, eds., The handbook of labor economics, Vol. 1, (North Holland, Amsterdam).

Pindyck, Robert S., and Julio J. Rotemberg, 1983, Dynamic factor demands and the effects of energy price shocks, American Economic Review 73, 1066-79.

Prescott, Edward C., 1986, Theory ahead of business cycle measurement, CarnegieRochester Conference Series on Public Policy 15, 11-44.

Rogerson, Richard D., 1988, Indivisible labor, lotteries, and equilibrium, Journal of Monetary Economics 21, 3-17.

Schor, Juliet B., 1987, Does work intensity respond to macroeconomic variables?:

Evidence from British manufacturing, 1970-86, Mimeo (Harvard University, Cambridge, MA).

Shapiro, Matthew D., 1986, The dynamic demand for capital and labor, Quarterly Journal of Economics 101, 513-542. 
Table 1: Evidence on Hours and Capital Utilization ${ }^{(A)}$

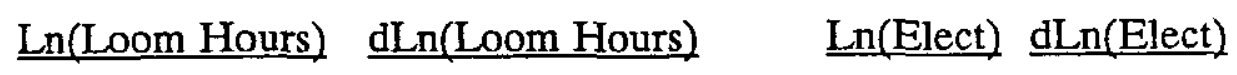

\begin{tabular}{|c|c|c|c|c|}
\hline Trend & $\begin{array}{l}-.0011 \\
(.0010)\end{array}$ & $\begin{array}{l}.00011 \\
(.000072)\end{array}$ & (B) & (B) \\
\hline$(\text { Trend })^{2}$ & $\begin{array}{l}.000028 \\
(.0000097)\end{array}$ & & (B) & \\
\hline 1st Quarter & $\begin{array}{l}.278 \\
(1.20)\end{array}$ & $\begin{array}{l}.053 \\
(.0091)\end{array}$ & & \\
\hline 2nd Quarter & $\begin{array}{l}.211 \\
(1.20)\end{array}$ & $\begin{array}{l}-.015 \\
(.0090)\end{array}$ & & \\
\hline 3rd Quarter & $\begin{array}{l}.155 \\
(1.20)\end{array}$ & $\begin{array}{l}-.056 \\
(.0089)\end{array}$ & & \\
\hline 4th Quarter & $\begin{array}{l}.173 \\
(1.20)\end{array}$ & $\begin{array}{l}.013 \\
(.0092)\end{array}$ & & \\
\hline Ln(Employment) & $\begin{array}{l}.166 \\
(.131)\end{array}$ & & $\begin{array}{l}.202 \\
(.046)\end{array}$ & \\
\hline Ln(Hours) & $\begin{array}{l}.941 \\
(.155)\end{array}$ & & $\begin{array}{l}1.253 \\
(.170)\end{array}$ & \\
\hline $\mathrm{dLn}($ Employment $)$ & & $\begin{array}{l}.424 \\
(.154)\end{array}$ & & $\begin{array}{l}.351 \\
(.052)\end{array}$ \\
\hline $\mathrm{dLn}$ (Hours) & & $\begin{array}{l}.921 \\
(.137)\end{array}$ & & $\begin{array}{l}.720 \\
(.180)\end{array}$ \\
\hline $\mathrm{R}^{2}$ & .710 & .648 & .171 & .169 \\
\hline SEE & .0346 & .0346 & .064 & .061 \\
\hline$\delta^{(\mathrm{C})}$ & $\begin{array}{l}.521 \\
(.090)\end{array}$ & $\begin{array}{l}-.470 \\
(.090)\end{array}$ & $\begin{array}{l}1.000 \\
(.0017)\end{array}$ & $\begin{array}{l}-.0946 \\
(.040)\end{array}$ \\
\hline $\mathrm{n}$ & 111 & 110 & 589 & 570 \\
\hline Period & \multicolumn{2}{|c|}{ Quarterly, 1958-85 } & \multicolumn{2}{|c|}{ Annual, 1954-85 } \\
\hline
\end{tabular}

\footnotetext{
(A) Standard errors appear in parentheses.

B) Industry-specific constant and trends were eliminated.

(C) The regressions each reflect a correction for first-order autocorrelation, where the autocorrelation parameter is $\delta$.
} 
Table 2: Behavior of Solow Residuals (total factor productivity) Under Alternative Cyclical Movements in Utilization

\begin{tabular}{ccc}
$\begin{array}{c}\text {--Solow 1-- } \\
\text { No Variations } \\
\text { in } \\
\text { Utilization }^{A}\end{array}$ & $\begin{array}{c}\text {--Solow 2-- } \\
\text { Variations in } \\
\text { Effort or } \\
\text { in Capital Use }\end{array}$ & $\begin{array}{c}\text {--Solow 3-- } \\
\text { Variations in } \\
\text { Effort and } \\
\text { in Capital Use }\end{array}$ \\
\hline
\end{tabular}

$\begin{array}{lccc}\rho & .950 & .932 & .850 \\ & (.020) & (.025) & (.040) \\ \sigma_{\epsilon} & .00745 & .00728 & .00768 \\ \sigma_{\mathrm{Z}} & .0239 & .0201 & .0146 \\ \operatorname{Corr}[\mathrm{Y}, \mathrm{Z}] & & & \\ \operatorname{Corr}[\mathrm{NH}, \mathrm{Z}] & .834 & .793 & .627 \\ \operatorname{Corr}[\mathrm{d}(\mathrm{NH}), \mathrm{dZ}] & . .093 & -.147 & -.282 \\ \operatorname{Corr}[\mathrm{d}(\mathrm{NH}), \mathrm{dZ}] & .114 & .582 & .325\end{array}$
(A) $\mathrm{Y}_{\mathrm{t}}=\mathrm{Z}_{\mathrm{t}}\left(\mathrm{N}_{\mathrm{t}} \mathrm{H}_{\mathrm{t}}\right)^{.64} \mathrm{~K}_{\mathrm{t}} \cdot 36$;
(B) $\mathrm{Y}_{\mathrm{t}}=\mathrm{Z}_{\mathrm{t}} \mathrm{N}_{\mathrm{t}}{ }^{.64} \mathrm{H}_{\mathrm{t}} \mathrm{K}_{\mathrm{t}}{ }^{.36}$;
(C) $\mathrm{Y}_{\mathrm{t}}=\mathrm{Z}_{\mathrm{t}} \mathrm{N}_{\mathrm{t}}^{.64} \mathrm{H}_{\mathrm{t}}{ }^{1.5} \mathrm{~K}_{\mathrm{t}}^{.36}$. 
Table 3: Relative Variabilities of Changes in Weeks per Year and Hours per Week in the Michigan PSID

\begin{tabular}{|c|c|c|}
\hline Time Period & $\frac{\text { Std. Dev. } \Delta \operatorname{Ln}(\mathrm{N})}{\text { Std. Dev. } \Delta \operatorname{Ln}(\mathrm{H})}$ & $\begin{array}{c}\# \\
\text { Observations }\end{array}$ \\
\hline $1970-71$ & 1.49 & 2177 \\
\hline $1971-72$ & 1.73 & 2298 \\
\hline $1972-73$ & 1.64 & 2435 \\
\hline $1973-74$ & 1.55 & 2576 \\
\hline $1974-75$ & 1.49 & 2720 \\
\hline $1975-76$ & 1.54 & 2878 \\
\hline $1976-77$ & 1.40 & 2948 \\
\hline $1977-78$ & 1.40 & 3076 \\
\hline $1978-79$ & 1.65 & 3226 \\
\hline $1979-80$ & 1.40 & 3333 \\
\hline $1980-81$ & 1.65 & 3395 \\
\hline $1981-82$ & 1.59 & 3472 \\
\hline $1982-83$ & 1.60 & 3339 \\
\hline $1983-84$ & 1.43 & 3493 \\
\hline $1984-85$ & 1.41 & 3801 \\
\hline $1985-86$ & 1.60 & 3980 \\
\hline Average & 1.54 & 49,127 \\
\hline
\end{tabular}


Table 4: Summary Statistics from U.S. Data

\begin{tabular}{llc}
\multicolumn{1}{c}{ Series } & $\begin{array}{c}\text { 'Standard } \\
\text { Deviation }\end{array}$ & $\begin{array}{c}\text { Correlation } \\
\text { with Output }\end{array}$ \\
\cline { 1 - 1 } Output (Y) & 1.74 & \\
Consumption (C) & 1.29 & 1.00 \\
Investment (X) & 8.45 & .85 \\
Capital Stock (K) & 0.63 & .91 \\
Aggregate Hours(Q) & 1.74 & .05 \\
Hours per week (H) & 0.46 & .77 \\
Employment (N) & 1.50 & .76 \\
Productivity (Py) & 1.18 & .81 \\
\end{tabular}

Note: (1) $\mathrm{Y}=$ real GNP, $\mathrm{C}=$ consumption of nondurables and services, $\mathrm{X}=$ gross private domestic investment, $\mathrm{K}=$ nonresidential equipment and structures, $\mathrm{Q}=$ hours of all persons, $\mathrm{H}=$ hours per person at work, $\mathrm{N}=$ all persons at work, and $\mathrm{Py}=$ output divided by aggregate hours. All series except consumption were taken from Citibase database. All series are seasonally adjusted, logged and detrended using Hodrick-Prescott filter. The standard deviations are in percentage term. Sample periods: 1955.3 - 1984.1.

(2) If, instead, we use the consumption series constructed by Lawrence Christiano, which includes flow of services from durables in addition to the consumption of nondurables and services, the standard deviation of consumption is 0.81 and the correlation with output is .65 . 
Table 5. Effects of Adjustment Costs

(A)

(B)

\begin{tabular}{|c|c|c|c|c|}
\hline Series & $\begin{array}{l}\text { Standard } \\
\text { Deviation }\end{array}$ & $\begin{array}{l}\text { Correlation } \\
\text { With Output }\end{array}$ & $\begin{array}{l}\text { Standard } \\
\text { Deviations }\end{array}$ & $\begin{array}{l}\text { Correlation } \\
\text { With Output }\end{array}$ \\
\hline Output (Y) & $\begin{array}{c}1.74 \\
(.21)\end{array}$ & $\begin{array}{c}1.00 \\
(.00)\end{array}$ & $\begin{array}{r}1.74 \\
(.24)\end{array}$ & $\begin{array}{c}1.00 \\
(.00)\end{array}$ \\
\hline Consumption (C) & $\begin{array}{l}.56 \\
(.09)\end{array}$ & $\begin{array}{c}.89 \\
(.03)\end{array}$ & $\begin{array}{c}.57 \\
(.11)\end{array}$ & $\begin{array}{c}.88 \\
(.03)\end{array}$ \\
\hline Investment $(\mathrm{X})$ & $\begin{array}{c}5.46 \\
(.62)\end{array}$ & $\begin{array}{c}.99 \\
(.00)\end{array}$ & $\begin{array}{c}5.47 \\
(.73)\end{array}$ & $\begin{array}{c}.99 \\
(.00)\end{array}$ \\
\hline Capital Stock (K) & $\begin{array}{l}.46 \\
(.11)\end{array}$ & $\begin{array}{c}.07 \\
(.07)\end{array}$ & $\begin{array}{l}.48 \\
(.13)\end{array}$ & $\begin{array}{c}.07 \\
(.06)\end{array}$ \\
\hline Aggregate Hours (Q) & $\begin{array}{l}.76 \\
(.09)\end{array}$ & $\begin{array}{c}.98 \\
(.00)\end{array}$ & $\begin{array}{l}.74 \\
(.10)\end{array}$ & $\begin{array}{c}.98 \\
(.01)\end{array}$ \\
\hline Hours $(\mathrm{H})$ & $\begin{array}{l}.26 \\
(.03)\end{array}$ & $\begin{array}{c}.98 \\
(.00)\end{array}$ & $\begin{array}{c}.27 \\
(.03)\end{array}$ & $\begin{array}{c}.97 \\
(.01)\end{array}$ \\
\hline Employment (N) & $\begin{array}{l}.50 \\
(.06)\end{array}$ & $\begin{array}{c}.98 \\
(.00)\end{array}$ & $\begin{array}{c}.47 \\
(.07)\end{array}$ & $\begin{array}{c}.98 \\
(.00)\end{array}$ \\
\hline Effort $(\phi)$ & $\begin{array}{l}.00 \\
(.00)\end{array}$ & $\begin{array}{c}.00 \\
(.00)\end{array}$ & $\begin{array}{l}.00 \\
(.00)\end{array}$ & $\begin{array}{c}.00 \\
(.00)\end{array}$ \\
\hline Productivity (Py) & $\begin{array}{l}1.02 \\
(.12)\end{array}$ & $\begin{array}{c}.99 \\
(.00)\end{array}$ & $\begin{array}{l}1.05 \\
(.15)\end{array}$ & $\begin{array}{l}.99 \\
(.00)\end{array}$ \\
\hline Tech. Shock & 1.02 & & 1.0 & \\
\hline
\end{tabular}

Note: The statistics reported are the sample means of statistics from each of one hundred simulations of 115 observations. The sample standard deviations are reported in parentheses. Each simulated series was logged and detrended by the same filter applied to the U.S. data. Standard deviations are in percentage term. The parameter values used are: (A) $\alpha=.64, \mu=0, \pi=0, \delta=.025$, a $=1.55$, b1 $=13.5$, b2 $=0, \sigma=1.576$, $\beta=2.0$, and $\tau=0$. (B) $\alpha=.64, \mu=0, \pi=.00969, \delta=.025, \mathrm{a}=1.55, \mathrm{~b} 1=13.5$, b2 $=0, \sigma=1.576, \beta=2.0$, and $\tau=0.0$. The AR(1) parameter in the technology shock process is .95 . 
Table 6. Effects of Utilization

(A)

(B)

\begin{tabular}{|c|c|c|c|}
\hline $\begin{array}{l}\text { Stand } \\
\text { Devia }\end{array}$ & $\begin{array}{l}\text { Correlation } \\
\text { With Outpu }\end{array}$ & $\begin{array}{l}\text { Standard } \\
\text { Deviations }\end{array}$ & $\begin{array}{l}\text { Corr } \\
\text { With }\end{array}$ \\
\hline
\end{tabular}

Series

Output (Y)

Consumption (C)

1.74

$(.25)$

.54

(.10)

Investment (X)

5.32

(.76)

Capital Stock (K)

.45

(.11)

.72

(.11)

.27

(.04)

.45

$(.07)$

.14

(.02)

Productivity (Py)

Tech. Shock
1.02

(.14)
1.00

$(.00)$

.88

(.03)

.99

$(.00)$

.07

(.08)

.99

(.00)

.97

(.01)

.98

(.00)

.97

(.01)

.99

(.00)
1.74

(.24)

.54

(.09)

5.65

(.73)

.48

(.11)

.74

(.10)

.30

(.04)

.45

(.07)

.15

(.02)

1.07

(.14)
1.00

(.00)

(.03)

(.00)

.06

(.06)

.99

(.00)

.96

(.01)

(.01)

.96

(.01)

.99

(.00)
.95

Note: The statistics reported are the sample means of statistics from each of one hundred simulations of 115 observations. The sample standard deviations are reported in parentheses. Each simulated series was logged and detrended by the same filter applied to the U.S. data. Standard deviations are in percentage term. The parameter values used are: (A) $\alpha=.64, \mu=0, \pi=.12, \delta=.025, \mathrm{a}=1.25, \mathrm{~b} 1=9.5, \mathrm{~b} 2=2.7, \sigma=$ $1.576, \beta=2.0$, and $\tau=3$. (B) $\alpha=.64, \mu=1, \pi=.00969, \delta=.025$, a $=.55$, b1 $=13.5$, $\mathrm{b} 2=4.2, \sigma=1.576, \beta=2.0$, and $\mathrm{o}=3.0$. The $\mathrm{AR}(1)$ parameter in the technology shock process is .95 . 
Table 7. Lower Persistence in the Technology Shock

\begin{tabular}{|c|c|c|}
\hline Series & $\begin{array}{l}\text { Standard } \\
\text { Deviation }\end{array}$ & $\begin{array}{l}\text { Correlation } \\
\text { With Output }\end{array}$ \\
\hline Output (Y) & $\begin{array}{c}1.74 \\
(.21)\end{array}$ & $\begin{array}{c}1.00 \\
(.00)\end{array}$ \\
\hline Consumption (C) & $\begin{array}{l}.36 \\
(.06)\end{array}$ & $\begin{array}{c}.69 \\
(.05)\end{array}$ \\
\hline Investment (X) & $\begin{array}{c}6.15 \\
(.72)\end{array}$ & $\begin{array}{l}.99 \\
(.00)\end{array}$ \\
\hline Capital Stock (K) & $\begin{array}{l}.46 \\
(.09)\end{array}$ & $\begin{array}{l}.02 \\
(.06)\end{array}$ \\
\hline Aggregate Hours (Q) & $\begin{array}{l}.82 \\
(.10)\end{array}$ & $\begin{array}{c}.98 \\
(.00)\end{array}$ \\
\hline Hours (H) & $\begin{array}{l}.36 \\
(.04)\end{array}$ & $\begin{array}{l}.97 \\
(.00)\end{array}$ \\
\hline Employment (N) & $\begin{array}{c}.49 \\
(.07)\end{array}$ & $\begin{array}{l}.97 \\
(.01)\end{array}$ \\
\hline Effort $(\phi)$ & $\begin{array}{l}.18 \\
(.02)\end{array}$ & $\begin{array}{l}.97 \\
(.00)\end{array}$ \\
\hline Productivity (Py) & $\begin{array}{l}.95 \\
(.11)\end{array}$ & $\begin{array}{l}.99 \\
(.00)\end{array}$ \\
\hline Tech. Shock & .7 & \\
\hline
\end{tabular}

Note: The statistics reported are the sample means of statistics from each of one hundred simulations of 115 observations. The sample standard deviations are reported in parentheses. Each simulated series was logged and detrended by the same filter applied to the U.S. data. Standard deviations are in percentage term. The parameter values used are: $\alpha=.64, \mu=1, \pi=.00969, \delta=.025, \mathrm{a}=.55, \mathrm{~b} 1=13.5, \mathrm{~b} 2=4.2, \sigma=1.576$, $\beta=2.0$, and $\tau=3.0$. The $\operatorname{AR}(1)$ parameter in the technology shock process is .85 . 
Table 8. Effects of Consumption Shock

\begin{tabular}{|c|c|c|}
\hline Series & $\begin{array}{l}\text { Standard } \\
\text { Deviation }\end{array}$ & $\begin{array}{l}\text { Correlation } \\
\text { With Output }\end{array}$ \\
\hline Output (Y) & $\begin{array}{c}1.74 \\
(.22)\end{array}$ & $\begin{array}{c}1.00 \\
(.00)\end{array}$ \\
\hline Consumption $(\mathrm{C})$ & $\begin{array}{c}.85 \\
(.11)\end{array}$ & $\begin{array}{c}.47 \\
\text { (.13) }\end{array}$ \\
\hline Investment $(\mathrm{X})$ & $\begin{array}{c}6.17 \\
(.76)\end{array}$ & $\begin{array}{l}.94 \\
(.02)\end{array}$ \\
\hline Capital Stock (K) & $\begin{array}{l}.46 \\
(.09)\end{array}$ & $\begin{array}{l}.02 \\
(.09)\end{array}$ \\
\hline Aggregate Hours (Q) & $\begin{array}{l}.93 \\
(.13)\end{array}$ & $\begin{array}{l}.95 \\
(.02)\end{array}$ \\
\hline Hours $(\mathrm{H})$ & $\begin{array}{c}.39 \\
(.05)\end{array}$ & $\begin{array}{c}.94 \\
(.01)\end{array}$ \\
\hline Employment (N) & $\begin{array}{l}.55 \\
(.08)\end{array}$ & $\begin{array}{c}.93 \\
(.02)\end{array}$ \\
\hline Effort $(\phi)$ & $\begin{array}{l}.20 \\
(.02)\end{array}$ & $\begin{array}{c}.94 \\
(.01)\end{array}$ \\
\hline Productivity (Py) & $\begin{array}{c}.95 \\
(.11)\end{array}$ & $\begin{array}{c}.96 \\
(.02)\end{array}$ \\
\hline Tech. Shock & \multicolumn{2}{|c|}{.755} \\
\hline Con. Shock & \multicolumn{2}{|c|}{.900} \\
\hline
\end{tabular}

Note: The statistics reported are the sample means of statistics from each of one hundred simulations of 115 observations. The sample standard deviations are reported in parentheses. Each simulated series was logged and detrended by the same filter applied to the U.S. data. Standard deviations are in percentage term. The parameter values used are: $\alpha=.64, \mu=1, \pi=.00969, \delta=.025, \mathrm{a}=.55, \mathrm{~b} 1=13.5, \mathrm{~b} 2=4.2, \sigma=1.576$, $\beta=2.0$, and $\tau=3.0$. The AR(1) parameter in the technology and consumption shocks are .85 and .94 respectively. 
FIGURE 1: Behavior of Labor's Share

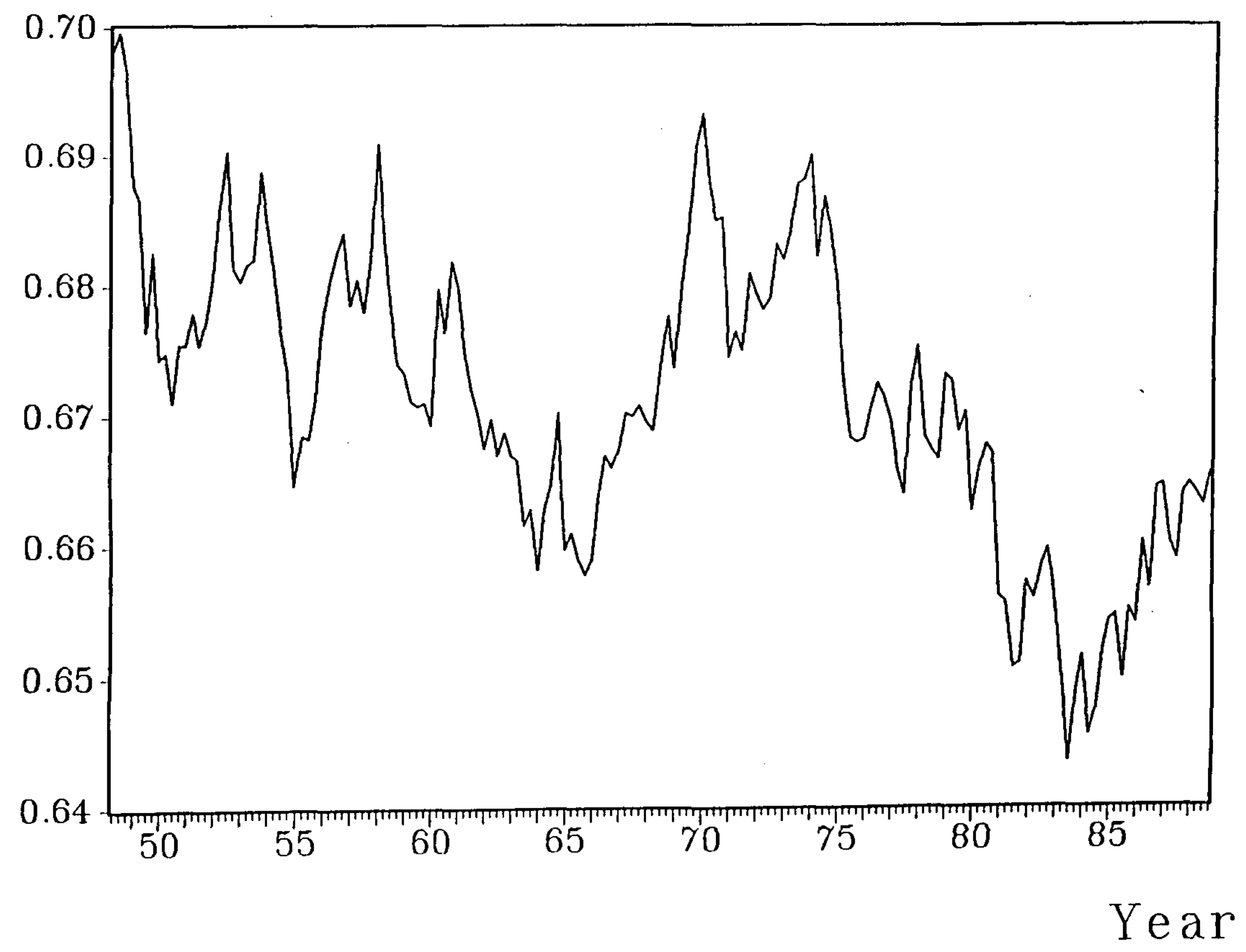


Figure 2: Long-run Impulse Responses: Technology Shock

(A) Output, Cons, and Investment

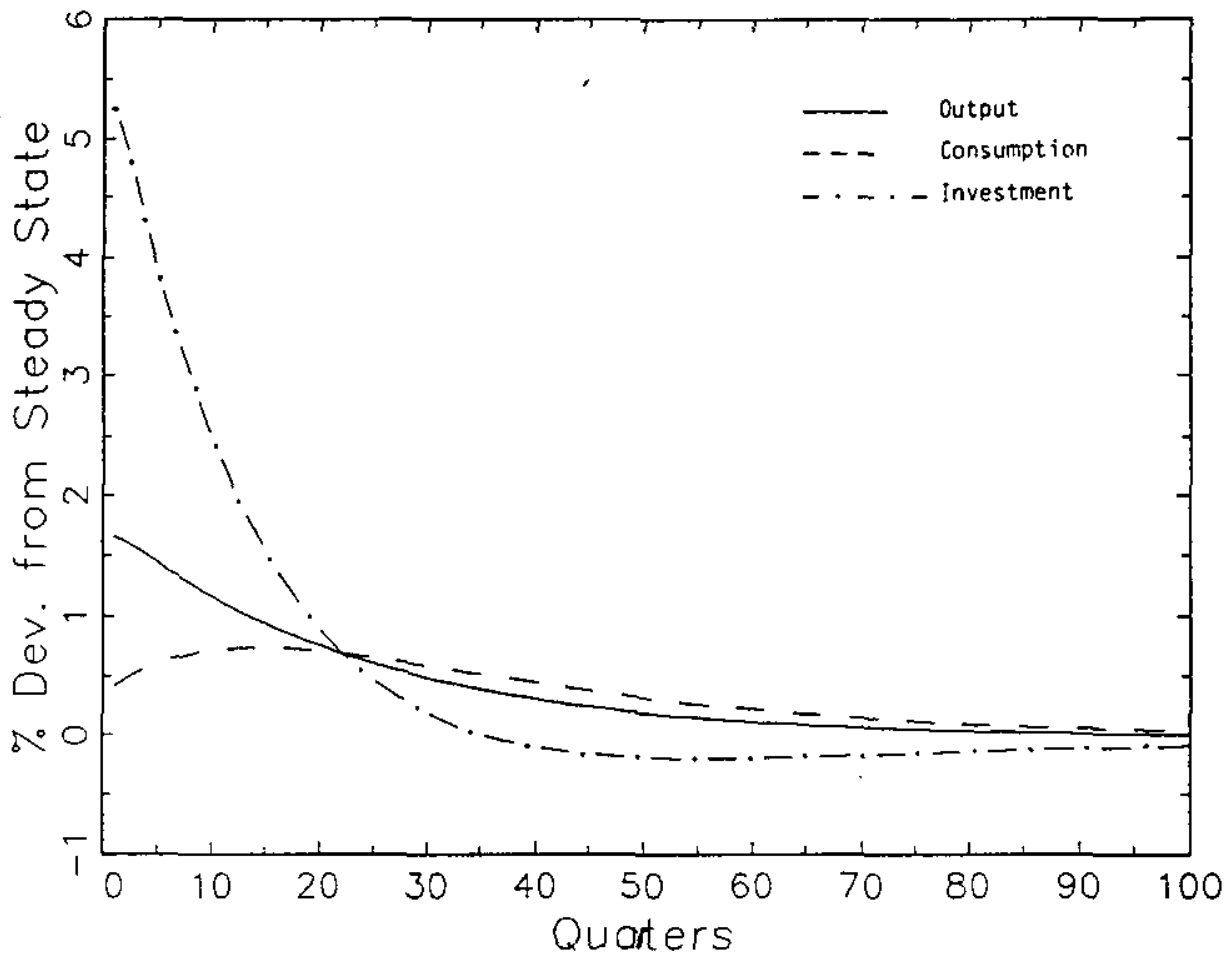

(B) Total Hours

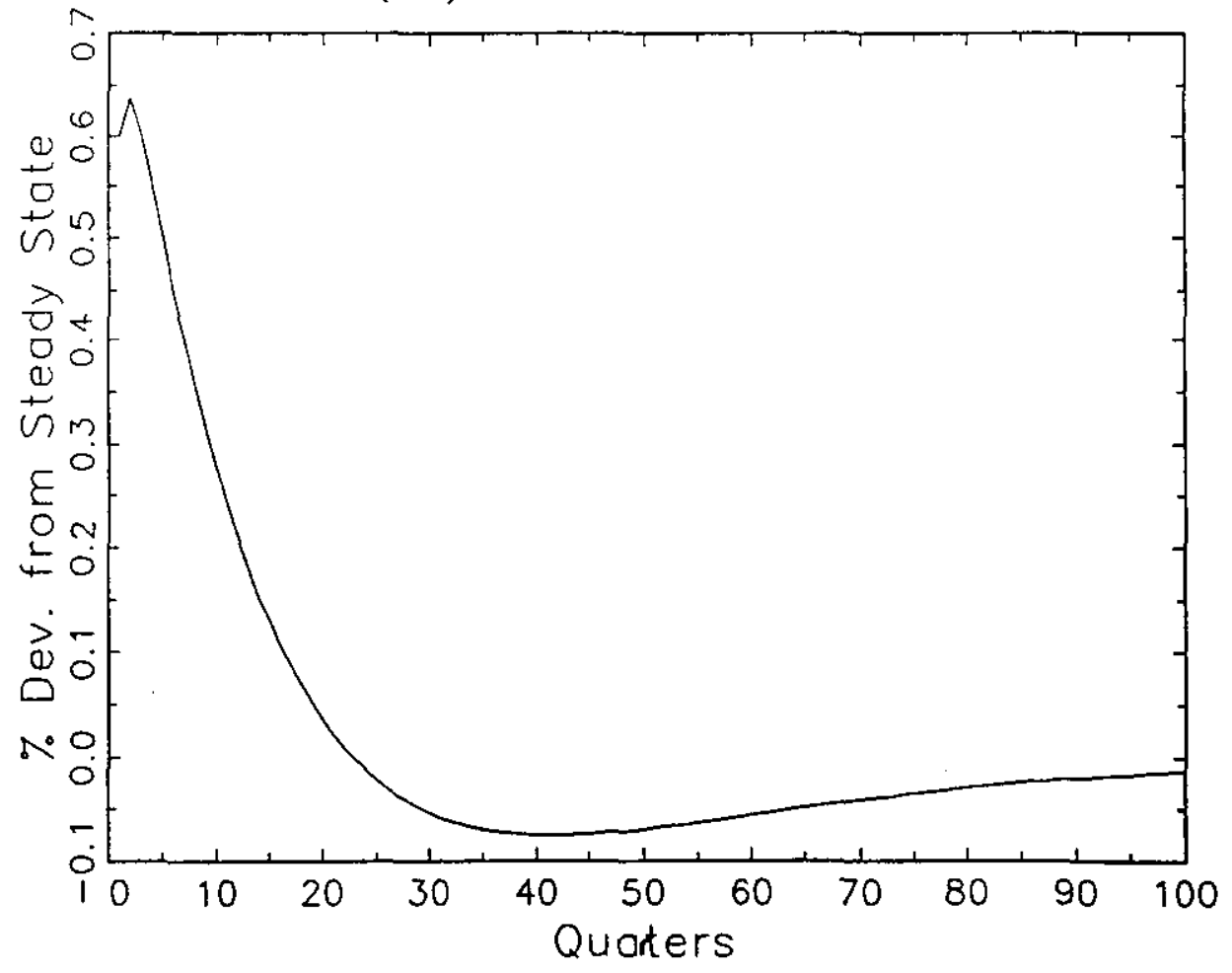


Figure 2: Continued
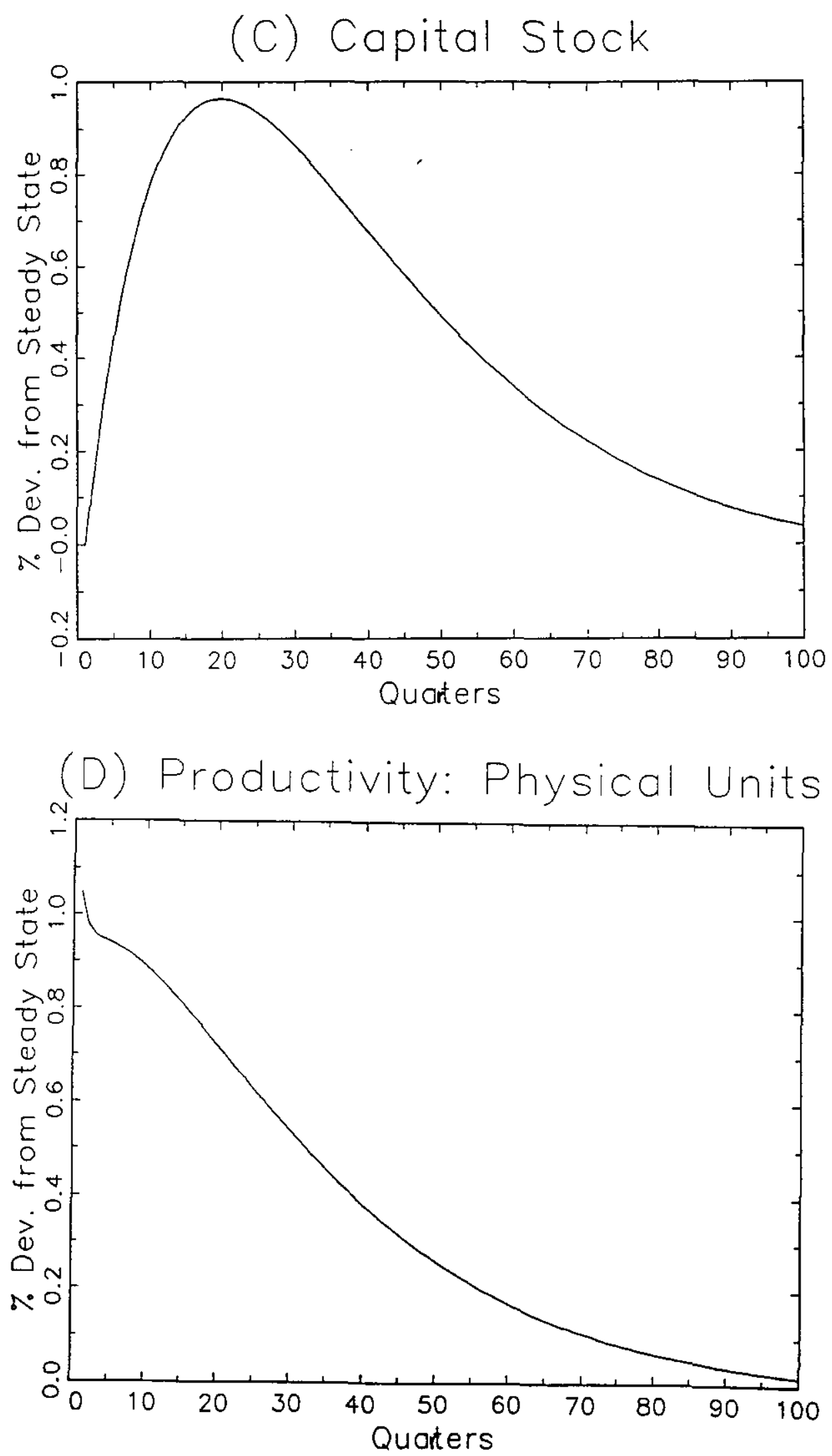
Figure 3: Short-run Impulse Responses: Technology Shock

(A) Total Physical Hours

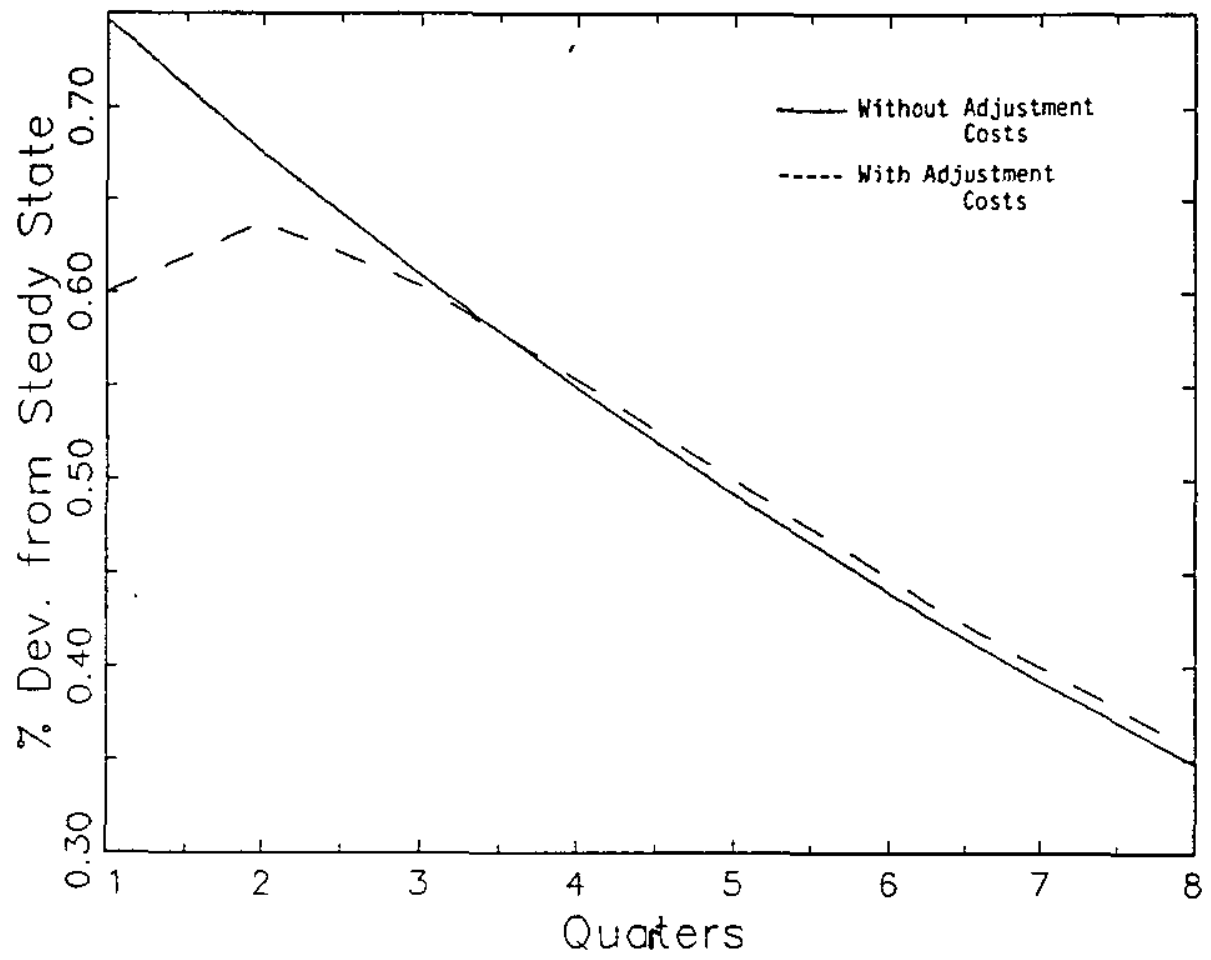

(B) Hours Per Week

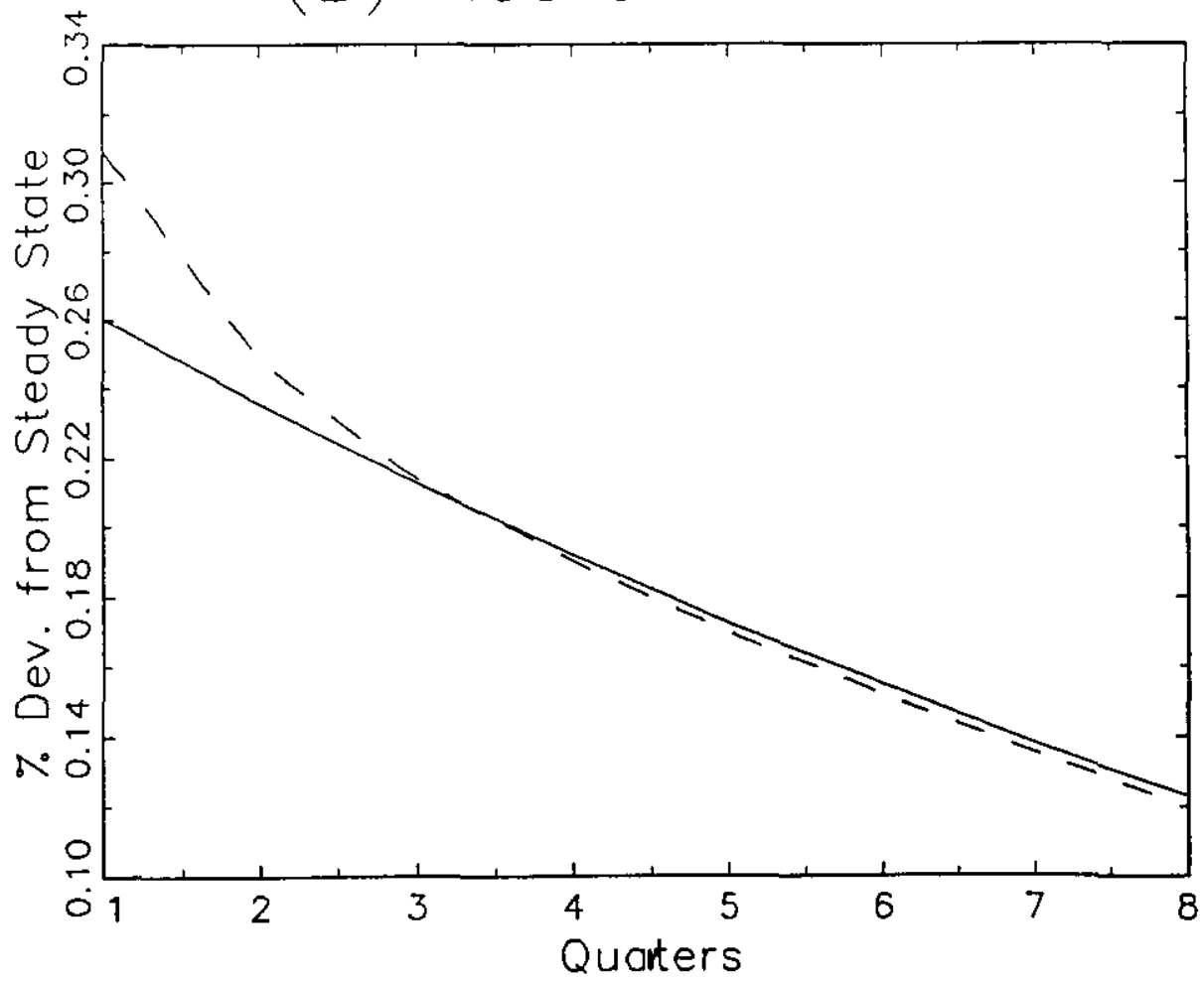


Figure 3: Continued
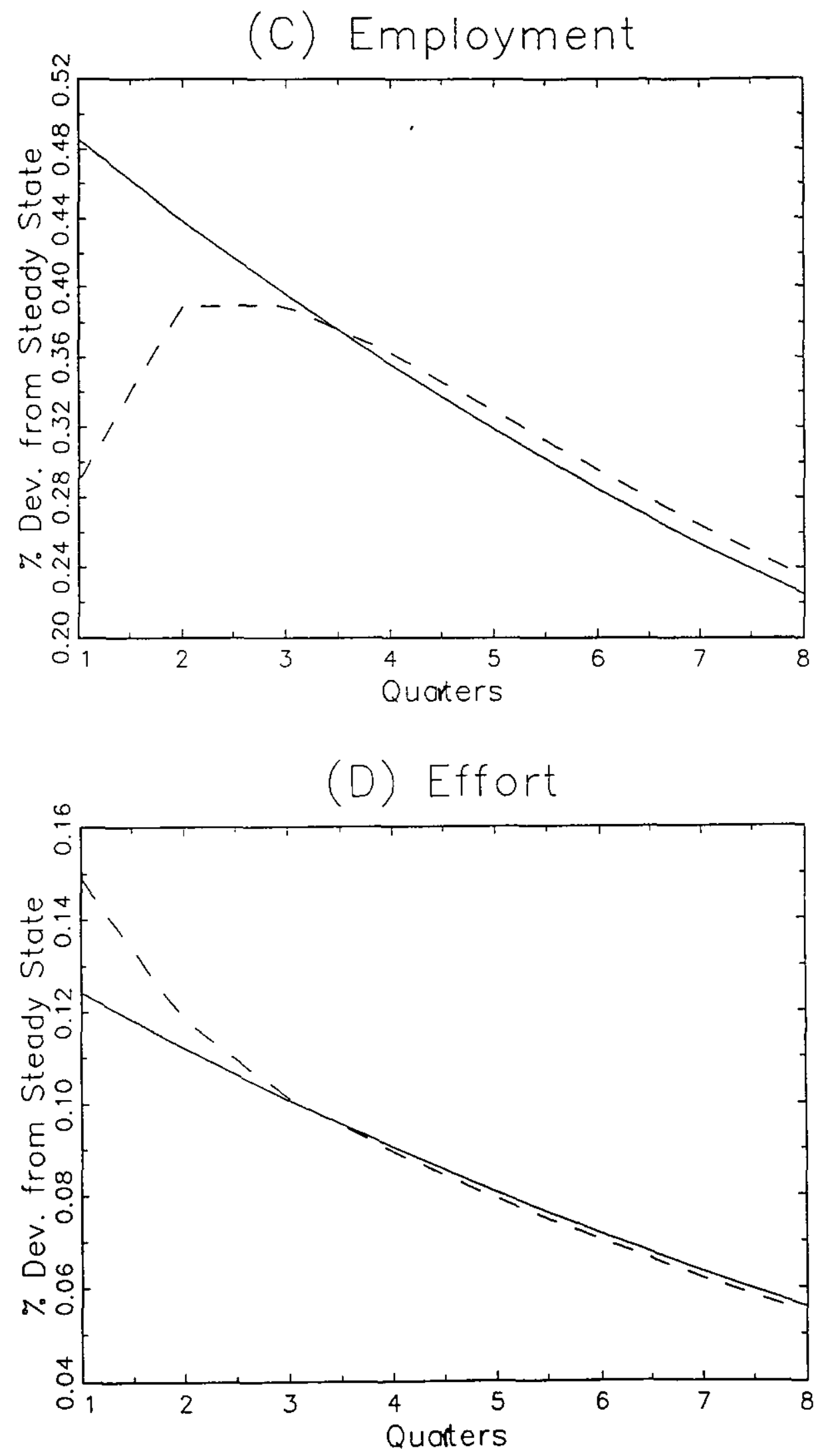
Figure 3: Continued
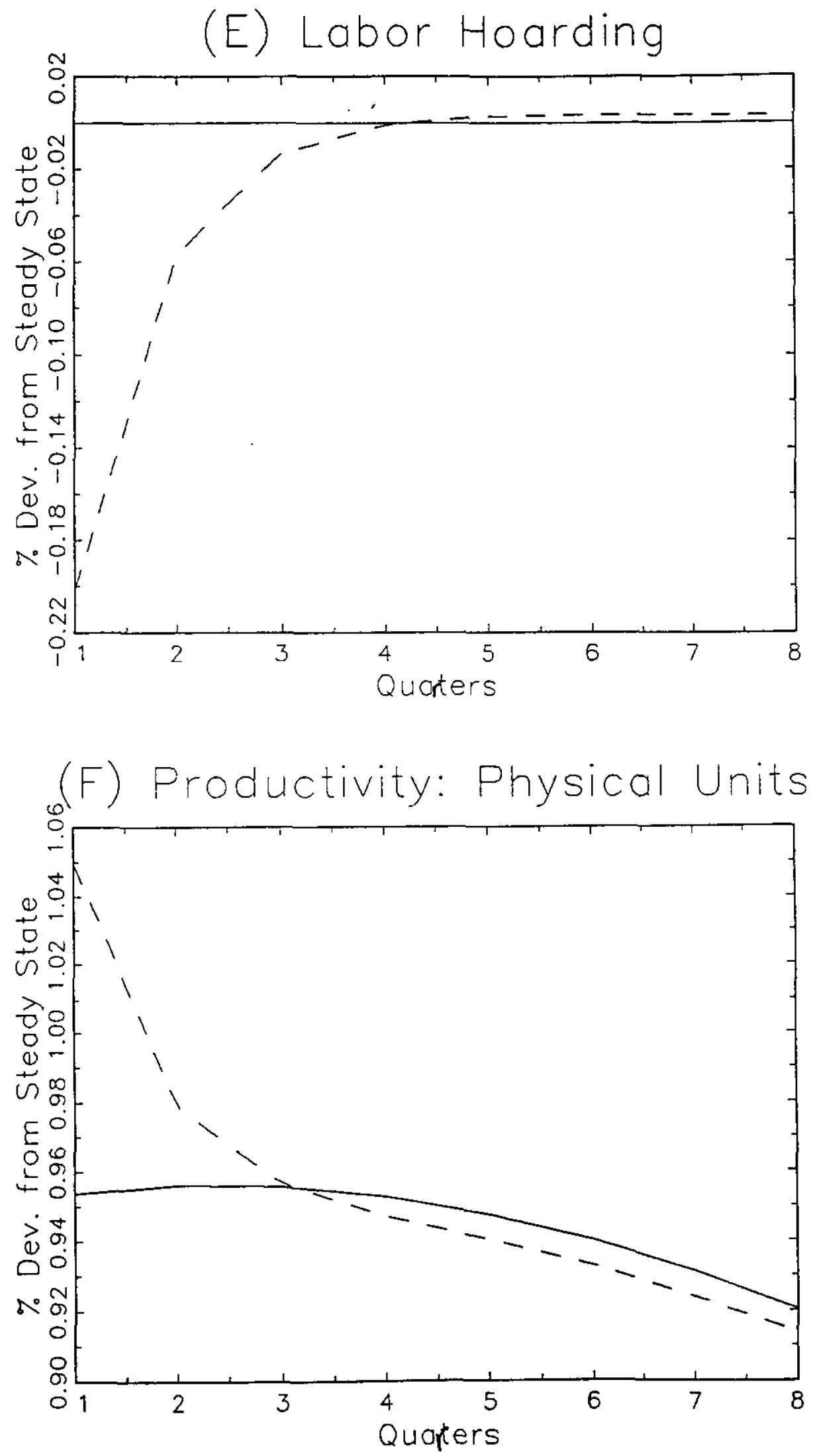
Figure 4: Impulse Responses: Consumption Shock
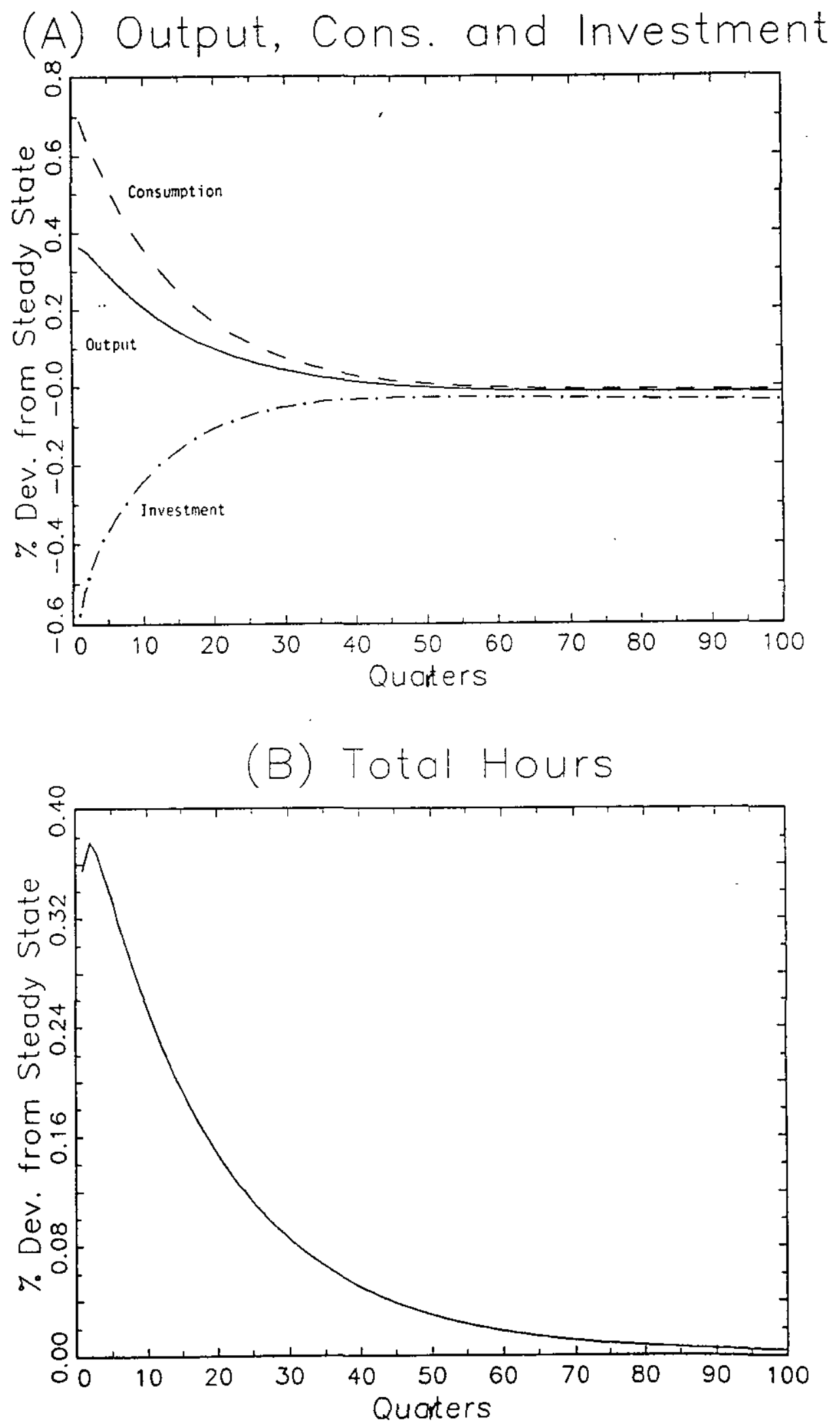
Figure 4: Continued
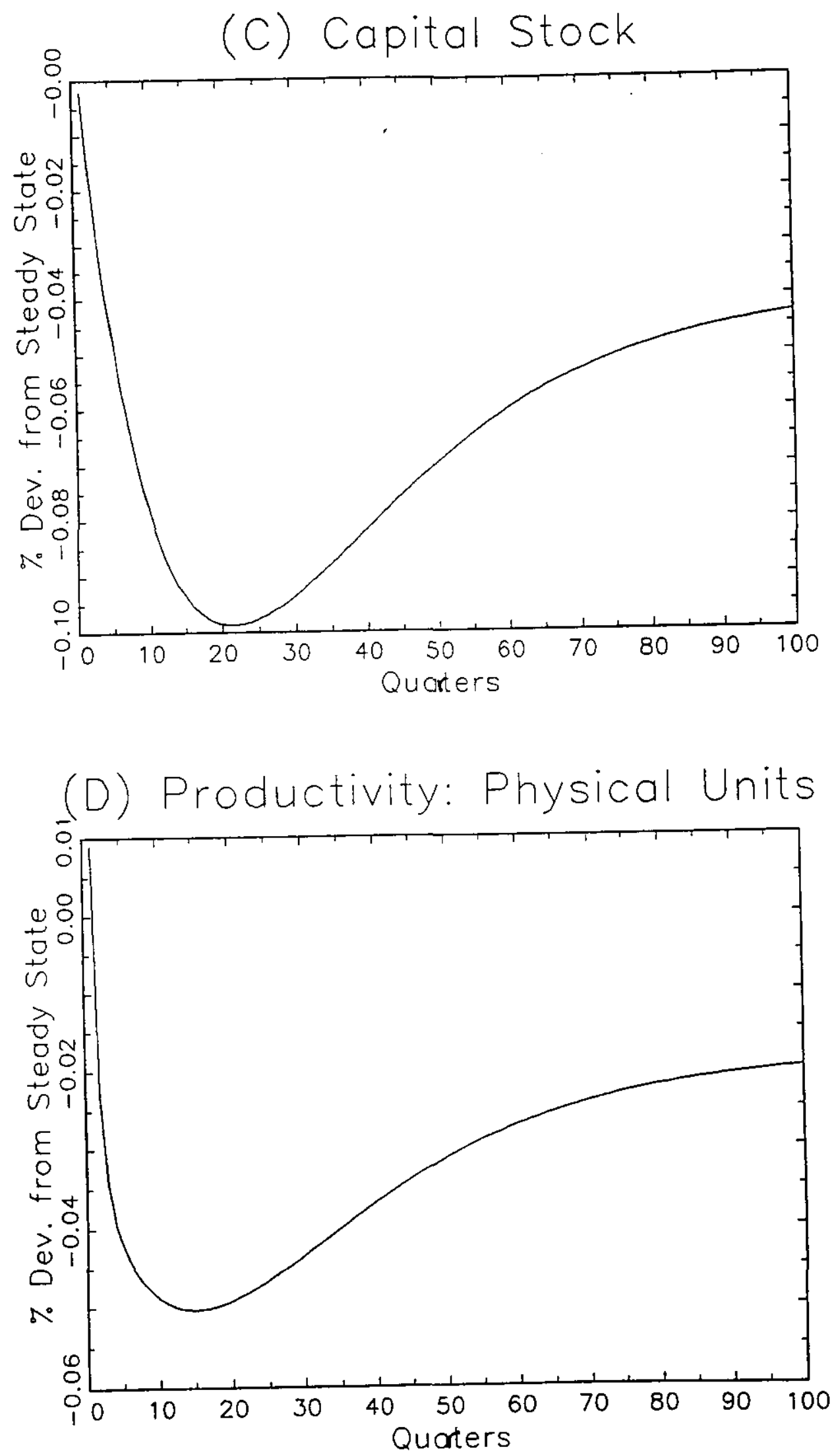
Figure 4: Continued

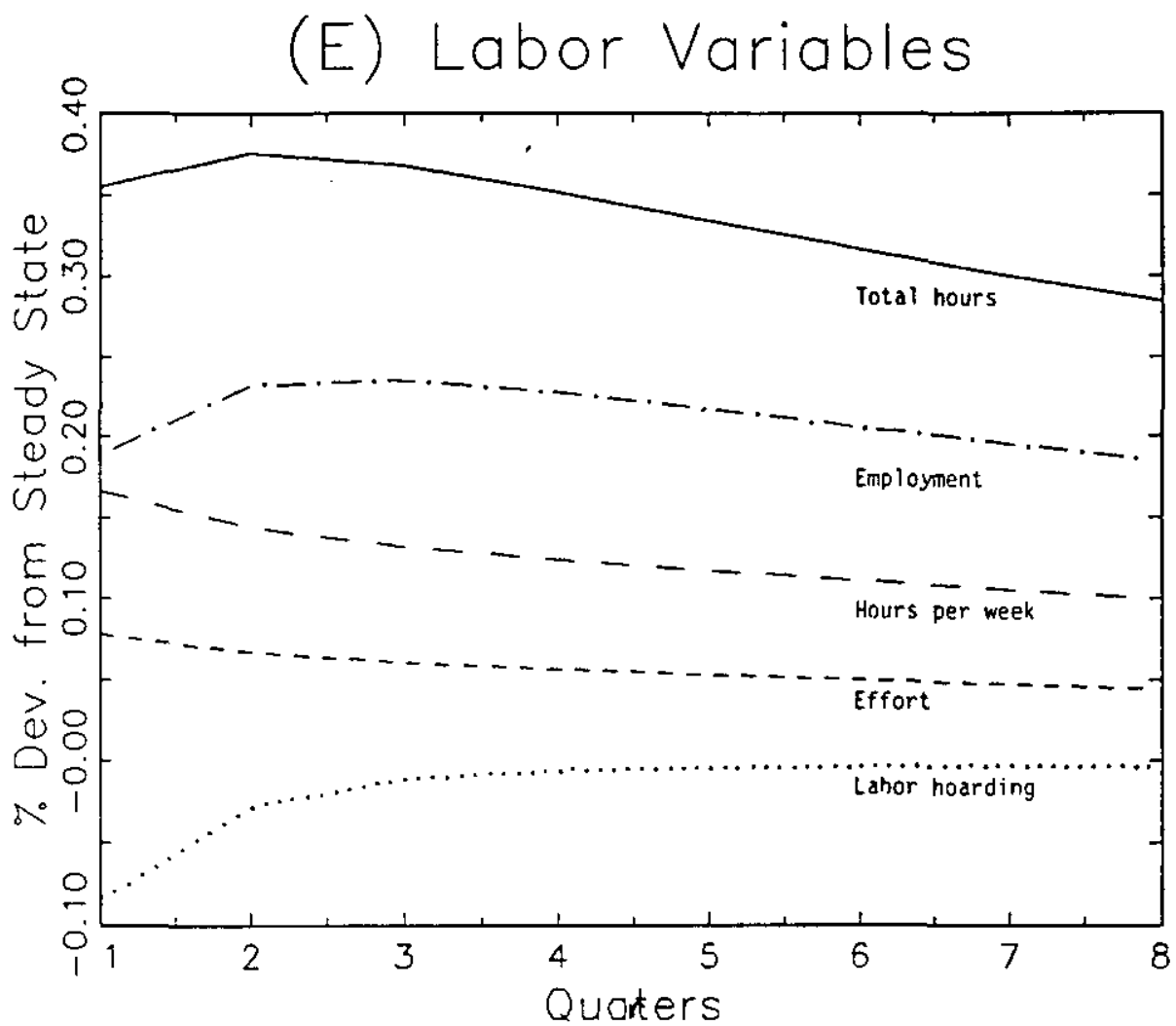

